\title{
JAPANESE CORPORATE GOVERNANCE: THE HIDDEN PROBLEMS OF CORPORATE LAW AND THEIR SOLUTIONS
}

\author{
BY ZENICHI SHISHIDO*
}

\begin{abstract}
It has long been said that Japanese corporate governance does not pay sufficient attention to shareholders as the owners of the corporation. Despite this seeming lack of shareholder ownership, Japanese firms have performed quite well until recently. This article seeks to solve this conundrum by demonstrating the "Company Community" concept as a positive model of the Japanese corporate govemance. This model illustrates how the Japanese system of corporate governance solves the hidden problems of corporate law. These hidden problems are common to all developed economies and consist of the dual challenge of balancing monitoring with the need for managerial autonomy and also balancing the trade off between money capital and human capital.

The Company Community concept solves these problems through an intricate three level system of monitoring. The first level is the in-house monitoring of management as a participant in the community by core employees who are quasi-residual claimants. The second level is the monitoring by cross-shareholders in the firm, particularly the main bank. Cross-shareholding has also had the effect of stabilizing the management position against outside control. The third level is the monitoring by exit of the outside shareholders. These multiple levels of monitoring stabilize management and uphold shareholder ownership as the end game norm.
\end{abstract}

The author is a professor of law at Seikei University Faculty of Law and was visiting professor of law at Columbia Law School 1998-1999. The author wishes to acknowledge the belpful comments of Richard Buxbaum, Stephen Choi, Melvin Eisenberg, Jesse Fried, Tomotaka Fujita, Andrew Guzman, Henry Hansmann, Curtis Milhaupt, Eric Otis, Mark Ramseyer, Andrzej Rapaczynski, Roberta Romano, Kenneth Scott, George Triantis, and Omri Yadlin. Thanks also go to seminar participants at Columbia, University of Illinois, Boston University, Harvard, and University of California Berkeley Law Schools for comments on an earlier draft. Aaron Brinkman provided skillful research assistance. article.

'The distinguished author translated and verified all Japanese sources included in this 
TABLE OF CONTENTS

I. INTRODUCTION $\ldots \ldots \ldots \ldots \ldots \ldots \ldots \ldots \ldots \ldots \ldots \ldots \ldots$

II. LEGAL SYSTEMS . . . . . . . . . . . . . . . . . . . . . 192

A. The Basic Legal Model of Corporations .......... 192

B. Differences Between the Legal Systems of the United States and Japan ..................... 194

III. JAPANESE PRACTICE WITH THE COMPANY COMMUNITY . . .. 201

A. The Company Community as the Key Concept ....... 201

B. Three Categories of Markets .............. 205

C. Monitoring Management ............... 208

IV. JAPANESE SOLUTIONS TO THE HIDDEN PROBLEMS OF CORPORATE LAW ............................. 209

A. Stabilizing Management by Cross-Shareholding .... 209

B. Employees as Quasi-Residual Claimants .......... 211

V. SHAREHOLDER OWNERSHIP AS THE END GAMENORM AND RECENT PHENOMENA ........................ 214 A. Employee Ownership? .................. 214

B. Emergence of the Real Owners in Recession ....... 215

VI. CONVERGENCE DEBATES AND THE FUTURE OF JAPANESE CoRPORATE GovernancE .................... 217

A. Criteria of Convergence ................ 218

B. Destiny of the Company Community ........... 222

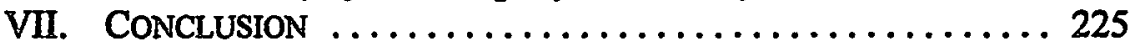

\section{INTRODUCTION}

A decade ago, T. Boone Pickens, the famous American corporate raider, criticized that shareholders of Japanese corporations are not given fair treatment as the owners of the corporation after he failed in his attempt to gain a directors' position in Koito Manufacturing Company, one of Toyota Motor's major parts suppliers. Mr. Pickens emerged to be the single largest shareholder after acquiring more than twenty percent of Koito's equity. ${ }^{1}$

The basic legal model of the corporation, whose essence is shareholder ownership, is congruent with the economic concept of efficiency. But why has Japanese corporate practice been so successful, at (1989).

'See Zenichi Shishido, A Texan Raid on a Japanese Company, 151-4 JAPAN Echo 61 
least until the end of the $1980 \mathrm{~s}^{2}$, with a practice that looks in many respects contrary to the basic legal model? ${ }^{3}$

This basic question leads to sub-inquiries. What is the legal model of the corporation? In particular, what does shareholder ownership mean? Why is it efficient? Japanese corporate governance is much more complicated than American corporate governance and, therefore, is easily misunderstood. This article will examine what Japanese corporate governance appears to be, followed by an analysis determining its true nature. Lastly, this article will discuss whether and why it could be efficient, in spite of its divergence from the basic legal model.

To solve the enigma of Japanese corporate governance, this article will pay attention to what corporate law does not say. Corporate law speaks nothing of methods to balance the monitoring and the autonomy of management, or how to further balance money capital providers and human capital providers. American corporate practice is also struggling to solve these two problems.

Japanese corporate governance is now in transition because of the drastic change of its background economic market. The typical Japanese model of publicly held corporations had been developed in the economic growth era and reached its heyday in the 1970s and 1980s. In the recession of the 1990s, the Japanese model is being forced to change. This article will focus on the historical model of 70 s and 80 s, then refer to the recent phenomena and future expectations.

Part II shows that the Japanese corporate legal system shares the same basics with the American corporate legal system and, at the least, is no less pro-shareholder ownership than its American counterpart. Part III illustrates

\footnotetext{
${ }^{2}$ Faced with fewer opportunities for reinvestment due to slow growth in the Japanese economy, firms that had previously reinvested profits heavily in expansion significantly decreased this practice in the 1980s. This led to large levels of free cash flows during this period (see Figure 1), which were largely misspent. Even in the bubble economy in the 1980s, the failure of the Japanese corporate govemance was evident in the misuse of free cash flows by management of Japanese corporations. See Shigeru Watanabe \& Isao Yamamoto, Nihon Kigyou no Kohporehto Gabanansu: Sengo Saitei no ROE kara [The Corporate Governance of Japanese Firms: The Lowest ROE After the War], 1992-9 Zaikai Kansoku [Business World Observer] 2, 12. Recessionary forces on the Japanese economy in the late 1980s required changes in the corporate governance of the Japanese firm, which were not made. See Steven N. Kaplan, Corporate Governance and Corporate Performance: A Comparison of Germany, Japan, and the U.S., in COMPARATIVECORPORATE GOVERNANCE 195, 202 (Klaus J. Hopt\& Eddy Wymeersch eds, 1997).

${ }^{3}$ It may be suggested that Japanese corporate governance mattered little, if at all, in the growth of the Japanese economy, but this growth was caused by intrinsic factors in the Japanese and world economy. It is argued here that the virtually unparalleled success of Japanese corporations in domestic and international markets is due, at least in part, to the unique design of the Japanese corporate governance system. The strength of the Japanese corporate govemance is illustrated by the fact that foreign owned subsidiaries doing business in Japan tend to take on a Japanese style of governance.
} 
Japanese corporate governance practice by using the concept "Company Community" and its relationship to the concept of "employee ownership." Part IV will fill the gap between the legal system and the practice from the perspective of solving the hidden problems of corporate law. Part $\mathrm{V}$ will show that Japanese corporate governance, not only its legal system but also in its practice, shares the basics of shareholder ownership as the end game norm, and will also show now this is indicated by recent phenomena. Part VI presents views on the contemporary debate over the convergence of corporate governance systems and future scenarios for Japanese corporate governance. ${ }^{4}$ Concluding remarks and a summary of the argument appear in Part VII.

\section{LEGAL SYSTEMS}

\section{A. The Basic Legal Model of Corporations}

This subsection explains the basics shared by Japanese and American corporate legal systems. The core concept is shareholder ownership of the firm, or more precisely, the relationship among assets, money, and people, as illustrated by Figure 2 .

The basic legal model of corporations, shown as Figure 2, has three points. First, the shareholders who provide money capital as equity holders while maintaining no legal right of reimbursement have the voting right, usually on a one-share, one-vote basis. Neither the debtholders, who are other important money capital providers, nor the employees, who are the providers of human capital, are given voting rights. ${ }^{5}$

Second, by a majority vote of stock, the shareholder meeting elects directors, and by a majority vote of the board members, the board of

'The article will illustrate the dynamics between corporate govemance and backyard economic markets, which is a point lacking in the current debate on the convergence in corporate govemance. See, e.g., Lucian Arye Bebchuk \& Mark J. Roe, A Theory of Path Dependence in Corporate Ownership and Governance, 52 STAN. L. REv. 127 (1999); John C. Coffee, Jr., The Future as History: The Prospects for Global Convergence in Corporate Governance and its Implications, 93 Nw.U.L.REV. 641 (1999); Ronald S. Gilson, Globalizing Corporate Governance: Convergence of Form or Function (Working Paper, on file with Columbia Law School); Curtis Milhaupt, Property Rights in Firms, 84 VA. L. REV. 1145 (1998); J. MARK RAMSEYER, ARE Corporate Governance Systems Convergng? (Working Paper, Sloan Project on Corporate Governance at Columbia Law School, 1998).

'This is the basic model. American law, i.e., state corporation statutes (e.g., DEL. CODE ANN. tit. 8, \$§ 151(a), 221 (1991)), generally does not prohibit debtholders from holding voting rights. See FRANK H. EASTERBROOK \& DANIEL R. FISCHEL, THE ECONOMIC STRUCTURE OF CORPORATE LAW 63 (1991). Typically, however, debtholders are given voting rights through shares, not as an addition to their rights as a debtholder. In practice, debtholders, employees, and management are often shareholders at the same time. 
directors elects management. The three-layered pyramidal structure, consisting of shareholders, the board of directors, and management, shows corporate governance in the narrow sense. ${ }^{6}$ The idea is that shareholders as owners (principals) allow board members as their agents to monitor management. ${ }^{7}$

Third, shareholders delegate discretionary powers to management via the board of directors. Consequently, management will have the power to order the hierarchy of employees, the power to buy and sell assets, and the power to determine the methods of financing. These discretionary powers can be called the control or the residual right. ${ }^{8}$

In summary, shareholders are the owners of the firm in the sense that they maintain control (residual rights) even though in delegating this control to management, they have only a residual claim. ${ }^{9}$ Shareholders retain the power to change management if it does not use the delegated discretionary power for maximizing the shareholders' interest.

This basic legal model of the corporation is shared by the United States and Japan and is congruent with the economic concept of efficiency. Shareholders are the residual claimants, who have the appropriate incentives to make discretionary decisions. ${ }^{10}$ Shareholders also have the least dispersed interests among the stakeholders, ${ }^{11}$ which will minimize the cost of collective action. ${ }^{12}$ A system where only shareholders have voting rights is efficient because multiple group voters will have dissimilar preferences and cannot obtain a consistent system of choices. ${ }^{13}$

${ }^{6}$ Arguments about corporate governance can be divided into two types: corporate governance in the narrow sense, and corporate governance in the broader sense. The former argues only the principal-agent relationship between shareholders and management. The latter considers stakeholders as the third essential player in the game of corporate governance. See John C. Coffee, Jr., Unstable Coalitions: Corporate Governance as a Multi-Player Game, 78 GEo. L.J. 1495, 1495-96 (1990).

${ }^{7}$ See Bengt Holmstrom, Moral Hazard and Observability, 10 BELL J. EcoN. 74 (1979).

'See Oliver HaRT, Firms, CONTRACTS, AND FinanCial STRUCtURE 30 (1995).

'See HENRY HANSMANN, THE OWNERSHIPOF ENTERPRISE 11-12 (1996). The residual right and the residual claim could be separated in theory. A non-residual claimant would, however, have little incentive to use the residual rights to maximize the value of the corporation.

${ }^{10}$ See EASTERBROOK \& FISCHEI, supra note 5, at 68.

"Stakeholders include "not only the shareholders, ... but also ... employees, consumers, creditors and other corporate 'stakeholders."' Margaret M. Blair \& Lynn A. Stout, A Team Production Theory of Corporate Law, 85 VA. L. REV. 247, 254 (1999).

${ }^{12}$ See HANSMANN, supra note 9, at 39, 62, 91, 288.

${ }^{13}$ See EASTERBROOK \& FISCHEL, supra note 5, at 69-70. 
Recently, some scholars have argued against the theory of shareholder ownership, and instead, view the corporation as a coalition of stakeholders. ${ }^{14}$ As a positive matter, in any country's corporate system, it is self-evident that stakeholders, such as employees, creditors, and trading partners, at least partially influence the direction of corporate management. Stakeholders monitor management to insure they keep their "promises" to the stakeholders. Management will thereby try to balance the pressures from multiple stakeholders and, as a result, further run the business toward the direction in which the compound vectors of monitoring point (see Figure 3). The length of each vector, demonstrating the amount of pressure, depends on the overall bargaining power of the stakeholders. ${ }^{15}$ Corporate law makes the vector of shareholders longer by giving them the power of replacing management. Although shareholders seldom use this power, ${ }^{16}$ shareholders' legal right to replace management will always play a significant role. Therefore, the corporate law system may be called a system of shareholder ownership.

\section{B. Differences Between the Legal Systems of the United States and Japan}

Although there are several differences between the legal systems of corporate governance of the United States and Japan, they still maintain the same basic structure. In this subsection, the differences related to the shareholder-management relationship and shareholder ownership are

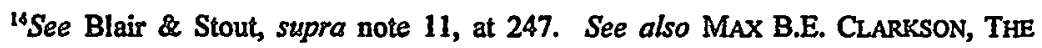
Corporation and ITS STAKeHOLders: Classic and Contemporary Readings (1998) (explaining how ownership interest is inseparable from stakeholder interests).

${ }^{15}$ See Zenichi Shishido, Institutional Investors and Corporate Governance in Japan, in, INSTITUTIONAL INVESTORS AND CORPORATE GOVERNANCE 665, 676 (Theodor Baums et al. eds., 1994). See also Masahiko Aoli, A Model of the Firm as a Stockholder-Employee Cooperative Game, 70 AM. ECON. REv. 600, 601 (1980) (explaining that both shareholders and employees share in organizational quasi-rent, and the managers act as arbiters between them); Coffee, supra note 6, at 1497, 1501 (concluding that management actions are often guided by unstated stakeholder interests).

"'Professors Blair and Stout argue:

In both theory and practice, however, shareholders' voting rights - at least in publicly-traded corporations - are so weak as to be virtually meaningless. The nominal existence of shareholder voting rights consequently does not pose a serious challenge to the mediating hierarchy model. In the vast majority of cases, shareholders' voting rights give them litule or no control over directors, who remain free to balance the interests of, and allocate rewards among, the various group that constitute the firm.

See Blair \& Stout, supra note 11 , at 310. 
discussed. ${ }^{17}$ Further analysis will then show that Japanese corporate law is more loyal to shareholder ownership than American corporate law.

The background procedural systems remain the largest differences between the United States and Japanese legal systems of corporate governance. The United States is a common law country with a flexible procedural system, while Japan is a civil law country with a less flexible procedural system. ${ }^{18}$ From a procedural point of view, it is easier for American shareholders to pursue legal remedies than for Japanese shareholders, who must choose an action from their respective Commercial Code. American shareholders also enjoy procedural advantages in pre-trial discovery, and the relatively easy availability of equitable remedies and class actions law suits.

In Japanese law suits involving corporations, the complaint must be modified to fit into one of the existing categories of suits provided under the Japanese Commercial Code. Japanese courts are bound to address only the legal issues raised by the parties themselves, and are thus bound by the plaintiffs request for relief. Courts are unable to balance conflicting interests of the parties except through the procedures of an agreed settlement. The American system, on the other hand, is much more flexible. Plaintiffs may bring a variety of suits against the corporation and courts may use equitable doctrines to provide relief whenever the law does not readily provide. Furthermore, American courts may provide relief beyond that requested in the parties' pleadings and raise motions on their own. ${ }^{19}$

\footnotetext{
${ }^{17}$ For a detailed study of this point, see Zenichi Shishido, Legal Monitoring Systems in Japan: Legal Possibilities and Current Practice, in PERSPECTIVES ON COMPANY LAW: 2, at 149 (Fiona Patfield ed., 1997). See also Curtis J. Milhaupt, A Relational Theory of Japanese Corporate Governance: Contract, Culture, and the Rule of Law, 37 HARV. INI'L L.J. 3, 4 (1996) (stating that the corporate govemance mechanisms of the United States differ dramatically from Japan's in the balance of constraints).

${ }^{18}$ See Zenichi Shishido, Problems of the Closely Held Corporation: A Comparative Study of the Japanese and American Legal Systems and a Critique of the Japanese Tentative Draft on Close Corporations, 38 AM. J. OF CoMP. L. 337, 342 (1990).

${ }^{19} \mathrm{An}$ example of these differences is a squeeze-out case in a closely held corporation. A squeeze-out case occurs when a majority shareholder attempts to siphon off profits in the form of officers' salaries, rather than paying dividends in order to force minority shareholders to sell their shares at a distress price. A U.S. court has many options to provide relief to the minority shareholders in such a case. Plaintiff minority shareholders can demand an accounting of the excessive salaries received by the majority shareholders, or they can demand a dividend. A court may find the salaries to be a waste of the corporate assets and order the majority to account for the amount above the level the court finds reasonable. It could also order the corporation to pay a dividend of a specified amount if the court considered the restrictions a violation of the business judgment rule. Or, finally, it could issue mandatory injunctions for distributions of profits, even if the plaintiffs had not requested this particular form of relief.

Japanese courts have limited authority to provide relief in this case. First, the minority shareholders must sue on grounds of abuse of discretion based on the resolution at a shareholder meeting to ratify the excessive salary or to not issue a dividend. If the minority shareholders are
} 
The protection of minority shareholders may also be an important function of corporate law and differs among countries. One influential article has asserted that these protections vary across countries, depending upon whether the origin of the legal system is common law or civil law. ${ }^{20}$ This article makes the claim, using empirical data, that common law systems give more minority shareholder protection and thus have more access to capital due to dispersed corporate ownership. However, the categorization of legal systems as common or civil law with respect to corporate ownership is too vague to be meaningful. ${ }^{21}$ The logical conclusion of this study would suggest that the Japanese system of corporate governance, as a civil law system, provides too few protections to minority shareholders to generate sufficient external capital for its firms.

As in the United States, shareholders in Japan hold many opportunities, beyond the right to vote their shares and to protect themselves from potential abuses by corporate management. La Porta et al. indexes minority shareholder protections in place throughout various countries, and further bases this index on five shareholder rights that may be embedded in the corporate law. ${ }^{22}$ The Japanese corporate legal system meets or exceeds all of these criteria. These include the ability to mail the proxy vote, ${ }^{23}$ the lack of a requirement to deposit shares prior to the general shareholders' meeting, ${ }^{24}$ cumulative voting, ${ }^{25}$ existence of a mechanism to relieve

successful in opposing the squeeze-out in the shareholder meeting, the majority must account for the increased salaries because the majority loses the legal right to retain it. The court in this case has no authority to determine what amount constitutes a reasonable salary. If the minority defeats the resolution not to issue a dividend, the minority must still wait until the next shareholder meeting at which time a resolution to pay a specific dividend will be decided. Japanese courts have no authority to order an affirmative act such as payment of a dividend. See id. at 342-43 and cases therein.

${ }^{20}$ See Rafael La Porta et al., Legal Determinants of External Finance, 52 J.Fin. 1131, 1132 (1997) (explaining common law affords more protections to shareholders and creditors than civil law).

${ }^{21}$ This important study by LaPorta et al. unfortunately relies on data and data classifications that are inherently unreliable. There are two main reasons for this unreliability. First, the classifications made to generate the data used in the empirical analysis are arbitrary. For example, they use the variable "antidirector rights" to measure shareholders' rights across countries. Underlying this variable are several components measuring whether cumulative voting is allowed and whether an oppressed minority statute is in place. See id. at 1134. The lack of a link between these legal measures and actual minority protections in publicly held corporations are obvious. Second, as applied to the Japanese case, this data does not reflect a realistic picture of the Japanese corporate law; and thus, leads to skewed conclusions.

${ }^{22}$ See id.

${ }^{23}$ See Securities Exchange Law $\$ 194$ (Japan); The Regulation on Proxy Solicitation (Japan); Special Exceptions Law of Commercial Code \& 21-3 (Japan).

${ }^{24}$ See Commercial Code $\$ \S 224,224-3,232$ (Japan).

${ }^{25}$ See Commercial Code § 256-3. 
oppressed minorities, ${ }^{26}$ and a minimum percentage of share capital required to call an extraordinary shareholders' meeting at or below ten percent. ${ }^{27}$

Beyond these basic measures of shareholder protection, Japanese corporate law allows the rights of inspection and proposal. The inspection right permits any shareholder owning more than three percent of a corporation's stock to request a court order to review the accounting books and other company documents. ${ }^{28}$ The proposal right allows shareholders that have owned more than one percent of shares or 300 shares for six months to make proposals to be considered at the shareholder meeting. ${ }^{29}$ A special voting of a two-thirds majority of stock is a mandatory requirement for fundamental changes. This means that more than a one-third minority has the power to veto fundamental changes. ${ }^{30}$

Aggrieved shareholders in Japan may also use a derivative action to sue directors of a corporation. ${ }^{31}$ Any single shareholder who owns stock for more than six months can file a derivative suit. ${ }^{32}$ In Japan, contemporaneous ownership is not required. ${ }^{33}$ After the 1994 passage of the Reform of the Commercial Code, a flat fee of about $\$ 80$ US $(\$ 8900)$ is required to file a derivative action. ${ }^{34}$ The fee was formerly a proportion of the total damages sought by the plaintiff. Accordingly, this legal reform substantially increased the number of shareholder derivative actions in Japan. ${ }^{35}$ Furthermore, Japanese corporations have less authority than American

${ }^{26}$ See Commercial Code $\$ 406-2$. The buyout right of stock with restricted transferability is also used in Japan as a relief measure for oppressed minorities. See Commercial Code § 204-2. Code $\$ 237$.

${ }^{27}$ The minimum level of ownership required in Japan is only three percent. See Commercial

${ }^{28}$ See Commercial Code $\$ 293-6$.

${ }^{29}$ See Commercial Code $\$ 232-2$.

${ }^{30}$ Commercial Code $\$ 408 \mathrm{III}$ (merger), $\S 245 \mathrm{I}$ (transfer of business), $\$ 343$ (altering the article of incorporation and bylaws), $\S 405$ (dissolution). The Japanese Commercial Code also requires special majority voting to discharge director during her tenure ( $\$ 257 \mathrm{II})$. Actually, it is difficult to evaluate whether special majority voting requirements as pro shareholder ownership or not. Although the intent of the Commercial Code is to protect minority shareholders, those special majority voting requirements could work as "shark repellants."

${ }^{31}$ See generally Roberta Romano, The Shareholder Suit: Litigation Without Foundation?, 7 J.L. ECON. \& ORG. 55 (1991) (discussing shareholder derivative actions).

${ }^{32}$ See Commercial Code $\$ 267$.

${ }^{33}$ Contemporaneous ownership is the requirement that only those who held shares at the time of a breach of a fiduciary duty may bring a derivative action. For the comparison of shareholder derivative actions, see Mark D. West, The Pricing of Shareholder Derivative Actions in Japan and the United States, 88 Nw. U. L. REv. 1436, 1455 (1998).

${ }^{34}$ See Commercial Code \$ 267 IV; Civil Suit Filing Fee Act § 4 II.

${ }^{35}$ The number of derivative action cases pending in Japanese district courts was 74 in 1993, 133 in 1994, and 158 in 1995 (statistics by the Supreme Court). 
corporations when deciding whether to file a derivative action. ${ }^{36}$ In the United States, rejection of the demand to file suit by independent directors will be weighed heavily by the court. ${ }^{37}$

Furthermore, the Japanese corporate law appears more loyal to the basics of shareholder ownership. In particular, the Japanese corporate law values the principle of stock majority more than its American counterpart. ${ }^{38}$ In the Japanese system, only shareholders may have voting rights, for it has been deemed unlawful to give voting rights to non-shareholders. ${ }^{39}$ Japanese shareholders have broader voting rights than American shareholders, including rights to determine dividends and executive compensation. ${ }^{40}$ Directors cannot be elected by either preferred shareholders or by different classes of common shareholders, for directors may be elected only by the common shareholders as a whole. Both non-voting stocks and stock repurchases are often used for stabilizing management positions in the United States, and are restricted in Japan. ${ }^{41}$ The only defensive measure Japanese management may use after a takeover offer is to issue stocks to white squires. ${ }^{42}$ Some poison pills, such as a corporate bond, which must be paid when more than five percent of stock is owned by a shareholder, could theoretically be used in Japan. This practice, however, has never been used in Japan and the Japanese courts' response is unpredictable. There is no antitakeover statute in Japan. For example, an arrangement which limits voting rights to ten percent, even for a shareholder who has more than ten percent equity, is not allowed..$^{43}$

${ }^{35}$ For the Japanese law governing board decisions on derivative actions, see Commercial Code, $\S 267$ II.

${ }^{37}$ See generally AMERICAN LAW INSTITUTE (AL), PRINCIPLES OF CORPORATE GOVERNANCE: ANALYSIS ANDRECOMMENDATIONS \$ 7.04(a)(2)(1994)(summarizing United States law).

${ }^{38}$ See MITSUHIRO FuKaO, FINANCIAL INTEGRATION, CORPORATE GOVERNANCE, AND THE PERformanCE OF MUltinational COMPANIES 4 (1995).

${ }^{39}$ American law generally does not prohibit giving debtholders voting rights. See supra note 5 and accompanying text.

${ }^{40}$ Commercial Code $\$ 283$ I (dividend), $\$ 269$ (the amount of compensation of the directors as a whole).

${ }^{41}$ Commercial Code $\$ \S 242$ I \& III (restrictions on non-voting stock); id. \$§ 210, 210-2, 210-3, 212-2 (restrictions on stock repurchase). See Shishido, supra note 17, at 157.

${ }^{42}$ Although the Commencial Code allows a shareholder to obtain an injunction against the unfair stock issuing (Commercial Code § 280-10), Japanese courts are agreeable to the incumbent management and seldom issue an injunction order. See In re Kobayashi Dep't Store Co., 493 Hanrei Jihoh 53 (Niigata Dist. Ct., Feb. 23, 1967) (Japan); In re Takuma Co., 1290 Hanrei Jihoh 144 (Osaka Dist. Ct., Nov. 18, 1987) (Japan); In re Miyairi Barubu Co., 1323 Hanrei Jihoh 48 (Tokyo Dist. Ct., Sept. 5, 1989) (Japan).

${ }^{40}$ For a discussion on antitakeover statutes in the United States, see VICTOR BRUDNEY \&

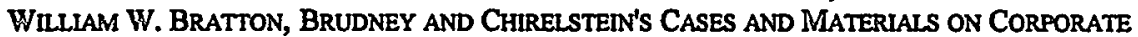
FINANCE 1142, 1142-48 (4th ed. 1993); Roberta Romano, The Future of Hostile Takeovers: 
From a different point of view, American corporate law is more flexible than Japanese corporate law, even for stabilizing management. Japanese corporate law is considered to be of a mandatory nature even in the area of corporate governance. If Japanese corporate law were flexible enough to allow shareholders to tailor the legal governance structure to better defend against hostile takeovers, then cross-shareholding, which is costly, would not be used in practice. It is, however, difficult to determine which scheme better balances the monitoring and the stabilization of management. ${ }^{44}$

The concept of fiduciary duty in Japan is also no less shareholderoriented than its American counterpart. The Japanese Commercial Code contains a statute on the fiduciary duty of directors to the company. ${ }^{45}$ The statutory phrase "fiduciary duty to the company" is generally interpreted by commentators as "duty to the shareholder." ${ }^{146}$ Also, no case law exists that explicitly allows the balancing of interests of stakeholders. The American concept of fiduciary duty used to be strict and straight forward, only requiring directors and officers to owe a fiduciary duty to shareholders. ${ }^{47}$ Recent phenomena in the United States, however, has given rise in many states to stakeholder statutes that allow directors and officers to balance the interests of stakeholders. ${ }^{48}$

In the United States, the business judgment rule plays an important role in giving management certain autonomy. Although Japanese courts are also reluctant to second-guess managerial decisions, the business judgment

Legislation and Public Opinion, 57 U. CIN. L. REV. 457 (1988) (surveying state and federal regulatory mechanisms for corporate takeovers).

${ }^{4}$ See infra notes 95-103 and accompanying text.

${ }^{43}$ Commercial Code $\$ 254-3$. Case law does not distinguish between the duty of care and the duty of loyalty. Arita v. Kojima (Yahata Steel Case), 24-6 MinsHO 625 (Sup. Ct, June 24, 1970). Actually, in Japan, there is no equivalent to the American concept of duty of loyalty, which prohibits agents from obtaining any personal gain. Japanese directors will not be liable as long as the corporation suffers no damage. Additionally, in Japan, there is no concept of the fiduciary duty on the part of the majority shareholders.

${ }^{15}$ See Misao Tatsuta, Kaisha Hoh [CoRporation LaW] 70 (6th ed. 1998).

${ }^{4}$ See Jonathan R. Macey, An Economic Analysis of the Various Rationales for Making Shareholders the Exclusive Beneficiaries of Corporate Fiduciary Duties, 21 STETSONL. REV. 23, 23 (1991) (explaining that the directors must manage the corporation to the exclusive benefit of shareholders).

${ }^{4}$ See Richard A. Booth, Stockholders, Stakeholders, and Bagholders (or How Investor Diversification Affects Fiduciary Duty), 53 Bus. LAw. 429, 429 (1998) (identifying the new trend of "other constituency" statutes); James J. Hanks, Jr., Playing with Fire: Nonshareholder Constituency Statutes in the 1990s, 21 STETSON L. REV. 97, 103-06 (1991) (surveying various nonshareholder constituency statutes); Roberta S. Karmel, Implications of the Stakeholder Model, 61 GEO. WASH.L. REv. 1156, 1162-65 (1993) (chronicling the legislative response to institutional activity); Eric W. Orts, Beyond Shareholders: Interpreting Corporate Constituency Statutes, 61 GEO. WASH. L. REV. 14, 31-35 (1992) (discussing the application constituency statutes). 
rule is not an established legal concept. In Japan, the distinction between the procedure of the decision and the substantial adequacy of the decision tends to be blurred. ${ }^{49}$

Another important difference in corporate governance is the board system. Although the basic three-layered pyramidal structure is common to both countries (see Figure 2), the Japanese board of directors is not as well separated from management as its American counterpart. In Japan, the board of directors elects representative directors from among board members, who subsequently become members of senior management. Thus, members of senior management must be elected by the board and will further sit as board members. ${ }^{50}$ In the United States, although the CEO is a board member for purposes of reporting to the board, members of upper management of American firms are not required to be board members by law. In Japan, the board of directors and the management are not as well separated legally and practically as in the United States. The rationale behind the Japanese system is that management should be elected from among directors, who are themselves elected by shareholders. In the United States, the board elects management on behalf of shareholders.

The statutory auditor system is also unique to Japan. The statutory auditor serves as a specialized monitor of illegal acts of directors. Statutory auditors are not members of the board, but are further permitted to attend board meetings and express opinions. ${ }^{51}$ Most importantly, the statutory auditor maintains the role of presenting an opinion on the annual financial statement to the shareholder meeting in an auditor's report. After 1993, the statutory auditor position must take two forms: the board of auditors and the outside auditor for large firms. ${ }^{52}$ The statutory auditor does not maintain decision-making power, but does have access to the debate on business at the board of director level..$^{\text {s3 }}$

${ }^{49}$ See Hideki Kanda, Kabunushi Daihyohsoshoh ni kansuru Rironteli Sokumen [Some Theoretical Aspects of Shareholder Derivative Suits], 1038 JuRIST 65, 68 (1994). It is an interesting comparison between the comments on the business judgment rule by leading corporate law text books in both countries. An American text book stated: "[T]he directors will not be held liable for the consequences of their exercise of business judgment - even for judgment that appear to have been a clear mistakes." ROBERT C. CLARK, CORPORATE LAW 123 (1986). Whereas a Japanese bookstated, "[T] he decision must be the one that ordinary business people under the same circumstances would recognize as reasonable and the extraordinarily unreasonable decision should be considered a violation of the duty." TATSUTA, supra note 46, at 92.

${ }^{30}$ See Commercial Code $\S 261 \mathrm{I}$.

sl See Commercial Code \$ 260-3.

${ }^{32}$ See Special Exceptions Law of Commercial Code § 18 (Japan).

${ }^{53}$ The statutory auditor serves a similar purpose to the German supervisory board concept. However, the supervisory board maintains decision-making power (whereas the statutory auditor does not), but does not enjoy access to the debate in the German management board. Thomas André, Jr., Some Reflections on German Corporate Governance: A Glimpse at German 


\section{- III. JAPANESE PRACTICE WTH THE COMPANY COMMUNTTY}

The previous section demonstrated that Japan and the United States share nearly identical corporate legal systems, and at the very least, the Japanese corporate law cannot be said to be less pro-shareholder than its American counterpart. Conversely, many will agree that Japanese corporate practice is employee-oriented rather than pro-shareholder. ${ }^{54}$ The object of this section is to formulate an image of Japanese corporate practice while further explaining its mechanics. Although this article is primarily based on the economic analysis of law and practice, this section focuses on observations of social norms which play important roles in Japanese corporate governance. 55

The Japanese corporate governance practice was developed during the post war reconstruction era and the rapid economic growth era, and further reached its heyday in the 1970 s and 1980 s. $^{56}$ Also, one cannot ignore the continuity Japanese corporate governance practices maintain from the post war zaibatsu companies. ${ }^{57}$ Due to a fundamental change in the Japanese economic environment, since the bubble crashed in the early $1990 \mathrm{~s}$, the Japanese corporate model has recently been forced to change. This section discusses the historical model of the 70s and 80s.

\section{A. The Company Community as the Key Concept}

Figure 4 represents an image of the practice of Japanese corporate governance. The largest distinction between this image and the image of the

Supervisory Boards, 70TULANEL.REV. 1819(1996) (discussing the supervisory boards of German public companies); Klaus J. Hopt, Labor Representation on Corporate Boards: Impacts and Problems for Corporate Governance and Economic Integration in Europe, 14 INT'L REV. L. \& ECON. 203 (1994) (discussing participation of labor representation in the decision making of the board).

${ }^{34}$ See Hideki Kanda, Trends in Japanese Corporate Governance, in COMPARATIVE CORPORATE GOVERNANCE 189 (Klaus J. Hopt \& Eddy Wymeersch eds., 1997).

${ }^{35}$ See generally Robert D. Cooter, Decentralized Law for a Complex Economy: The Structural Approach to Adjudicating the New Law Merchant, 144 U. PA. L. REV. 1643 (1996) (explaining the relationship between economic analysis and social norms).

${ }^{56}$ See Hideaki Miyajima, Zaibatsu Tsuihoh to Keieisha no Senbatsu: Joutaiizonteki Gabanansu Sutorakuchua no Keisei [Expulsion of Zaibatsu and Choice of Management: Creation of Situation Dependent Governance Structure], in NHON KIGYOU SHISUTEMU NOSENGOSH [POST WAR HISTORY OF JAPANESE CORPORATE SYSTEM] 44 (Juro Hashimoto ed., 1996).

${ }^{57}$ The aggregate stockholding system [sohyuh sei] of the zaibatsu families prevented individual shareholders from intervening in management. Also, internal promotion of top management resulted in continuity. See TAKEOKIKKAWA, NIHONNOKIGYOU SHUHDAN: ZAIBATSU TONO RENZOKU TO DANZETSU [JAPANESE COMPANY GROUPS: CONTINUITY AND DISCONTINUITY FROM ZAIBATSU] 29 (1996). 
basic legal system (see Figure 2) is the location of employees. In Japanese practice, employees are located in the center of corporate governance, while in the basic legal system, they are located outside of the corporate governance. Employees are, at least within their own mind-set, not employed by the company, but rather belong to the "Company Community. ${ }^{158}$ The concept of Company Community is the key to understanding Japanese corporate governance. ${ }^{59}$

The Company Community consists of management, board members, and core employees who share an identity as "company men." In Japan, the word "company" refers to the collective Company Community. The Company Community provides a raison d'être for its members and plays a role as a competing unit in the product market. Within their own minds, members of the Company Community owe their loyalty to both the Community itself and their fellow members.

The scope of employee involvement in the Company Community is subject to controversy. The widest interpretation is that all full-time employees, including skilled and unskilled laborers, are members of the Company Community. Although this is the formal interpretation propounded by management, the actual scope of membership is in reality smaller. Company Community membership pertains to male white-collar full time employees, since they maintain a remote possibility to be the president or a board member. Female workers, even if full-time employees, have been considered to be only a temporary workforce and thereby ineligible for membership in the Company Community. This characterization is founded upon the heavy reliance on continuity, which the Company Community uses to distinguish between insiders and outsiders.

When considering the relationship between labor and management in Japan, it is necessary to distinguish between white-collar and blue-collar workers. White-collar workers have had the labor management relationship

\footnotetext{
${ }^{53}$ For arguments that pay attention to the community aspect of Japanese companies, see JURO HASHIMOTO, NIHON KEIZAI RON: NIJUSSEIKI SISUTEMU TO NIHON KEIZAI [A PERSPECTIVE OF JAPANESE ECONOMY: THE TWENTY CENTURY SYSTEM AND JAPANESE ECONOMY] 184 (1991); Ronald Dore, Equality-Efficiency Trade-offs: Japanese Perspectives and Choices, in THE JAPANESE FIRM: THE SOURCE OF COMPETITIVE STRENGTH 379 (Masahiko Aoki \& Ronald Dore eds., 1994).

59The Company Community is the author's hypothesis to explain the Japanese practice of corporate govemance. To explain how this community is historically formed and słays together is the author's future project. It appears, however, obvious that the important turning point was the purge of the old management by the cccupation amy after World War II and the election of new management from among the middle manager employees. See Zenichi Shishido, Reform in Japanese Corporate Law and Corporate Govemance: Current Changes in Historical Perspective (Working Paper presented atFourth Sho Sato Conference on Jkganese and U.S. Law: Legal Reform and Socio-Legal Changes in Japan, at Boalt Hall School of Law, University of Califomia, Beriseley, November 1999).
} 
digested into the Japanese corporate governance system. Blue-collar workers, however, are still recognized as having a labor management relationship and management attempts to employ a community-type approach in dealing with these employees as well. ${ }^{60}$ In Japan, all full-time blue-collar employees, as with white-collar employees, have traditionally been given the implicit promise of lifetime employment. This policy harmonizes the interests of employees with the interests of the corporation by forcing an employee's pending future success to become dependent upon the success of the firm. Furthermore, this policy breeds a "companyism" that not only motivates workers to be productive but also further fosters the famous "Japanese management style, ${ }^{1161}$ where managers gather important information and suggestions from blue-collar workers. ${ }^{62}$

Upon being hired, members of the Company Community are immediately given tenure, ${ }^{63}$ ensuring lifetime employment. ${ }^{64}$ Generally speaking, every company grants this privilege for the sake of creating the Company Community. Additionally, the Company Community model does not allow individuals to change communities. Therefore, the existence of the Company Community itself has limited the development of the external

${ }^{60}$ White collarization of blue-collar workers can be historically observed since the pre-war era. See Shinji Sugiyama, Nihonteki Koyohkankei no Keisei: Shuhgyoh Kisoku, Chingin, "Juhgyohin" [Development of Japanese Employment Relationship: Working Rules, Payment, and "Employee"], in NIHON KeIEISHI [JaPANESE MANAGEMENT HISTORY]4, 194 (1995).

The relationship of Japanese labor management to blue-collar workers has been successfully implanted both in developed countries and developing countries by Japanese companies, along with their direct investments in the world. See TETSUO ABO [ED.], NIHONIEKI KEIE, SEISAN SisuTEMU TO AMERIKa [JAPANESE MANAGEMENT, MANUFACTURING SYSTEM AND THE UNITED STATES] (1994); Hiroshi Itagaxi [ED.], Nihonteki Keigl, Seisan Sisutemu to Higashi A IIA [Japanese MaNAGEMENT, MaNUfacturing SyStem and EAST ASIA] (1997).

${ }^{61}$ This aphorism, commonly known to anyone reading the management literature of the 1980 s, refers to the fact that the Japanese labor-management relationship fosters much more interaction between line managers, for example, and line workers. In this system, the knowledge of the line worker is an important component in the production process, as is his skill and manual ability.

${ }^{62}$ The most successful accomplishment of Japanese labor management style is the Toyota Production System, on which numerous studies have been published. See, e.g., YasUHIRO MONDEN, TOYOTA PRODUCTION SYSTEM: AN INTEGRATED APPROACH TO JUST-IN-TIME (1993); TAICHI OHNo, TOYota PROduction System: BeyONd LARge-SCALE Production (1988).

${ }^{63}$ That is, they are given tenure just after their graduation from college. The only existing labor market for white-collar workers has been for new graduates.

${ }^{64}$ Lifetime in this context refers to the retirement age of approximately 55 years of age. Labor law cases have also supported the custom. See In re Kohchi Hohsoh, 268 Rohhan 17 (Sup. C. Jan. 31, 1977); In re Toyo Sanso, 30 Rohminshuh 1002 (Tokyo Appellate Ct., Oct. 29, 1979); Chih-Poung Liou, Nihon Rohdohhohniokeru Kaikoken Ranyoh Hohrino Keisi: Sengo kara Showa 35 nen madeno Saibanrei wo Chuhshin to shite [The Doctrine of Abused Dismissal in Japanese Labor Law: Cases from the End of the War until Showa 35] (Japan International Labor Law Fonm Special Series No. 5, 1999, Working Paper). 
labor market. The premise of this long-term relationship, ${ }^{65}$ that the company will not fire employees and employees will not quit, created characteristic Japanese corporate practices, such as investing in the training of employees and employee development of firm-specific skills. ${ }^{65}$

Seniority and egalitarian systems also support the concept of Company Community. For the first fifteen years, distribution of position and pay is basically equal among employees with the same seniority. This practice avoids excessive dissension among the members and keeps the community stable. ${ }^{67}$ Fifteen years after joining the community successful members and non-successful members are gradually differentiated. This practice forces members of the community to participate in long-term competition and gives them incentive to work harder. The distribution of aggregate lifetime payments across employees, rather than evidencing strong competition for promotion, is surprisingly egalitarian when compared to the United States. ${ }^{68}$

Another distinct practice of the Japanese legal system is the concept of the ununified shareholder. Shareholders of a Japanese company are divided into two categories: the inside and outside shareholders. The inside shareholders are considered stabilized, for they buy and hold their shares under an agreement with the management. They are basically crossshareholding partners, that includes the main bank. Although inside shareholders may have a voice in corporate governance during a crisis, they usually will not intervene in the Company Community. According to a Japanese social norm, the Company Community is always considered independent. Other companies, even if they are major shareholders in another corporation, should not intervene in decision making by the

${ }^{65}$ Valuing the long-term relationship is a distinctive social norm in Japan. It is observed not only between the company and its employees, but also between the company and its shareholders, and between trading partners.

${ }^{6}$ Professors Ronald Gilson and Mark Roe comment: "LL]ifetime employment (the 'bright' side of Japanese labor practices) is tied to the lack of an external labor market (the 'dark' side of Japanese labor practices), and this 'dark' side does more of the 'work' in encouraging employee productivity and commitment to the firm than lifetime employment." Ronald J. Gilson \& Mark J. Roe, Lifetime Employment: Labor Peace and the Evolution of Japanese Corporate Governance, 99 CoLUM. L. REv. 508, 509 (1999). Although they correctly focus on lifetime employment and the lack of an external labor market as one component of the story, these do not represent the whole story. Analysis of the concepts of lifetime employment and the lack of an external labor market ignoring the institutional framework of the Company Community, would not be complete. Lifetime employment is an indispensable factor of the Company Community, and in that sense it plays an important role to give employees incentives to make a commitment to the company.

${ }^{67}$ Such an equal sharing rule to avoid dissension among the members is analogous to employee owned firms. See, e.g., HANSMANN, supra note 9, at 92.

${ }^{68}$ Egalitarianism is also a distinctive social norm in Japan. 
Company Community. ${ }^{69}$ The outside shareholder turnover rate is higher, since they include both domestic individuals and foreigners (see Figure 5) ${ }^{70}$ Outside shareholders are not recognized in corporate governance, but only in the financial market. Since outside shareholders have no voice, ${ }^{71}$ the only way for them to voice disapproval is by exit.

\section{B. Three Categories of Markets}

Japanese markets may be categorized into three types (see Figure 4): the free competition markets (square with sequent line), the organized markets (oval), and the incomplete markets (square with dotted line). The distinction between market and hierarchy is blurred in Japan. The different characteristics of these markets affect corporate governance.

An example of this is the different methods used to divide "managing units. "72 In the United States, managing units that were formerly combined in a single firm are often spun-off from the parent corporation in a free competition market solution. ${ }^{73}$ In Japan, the same is accomplished using a parent-subsidiary relationship in an organized market solution. ${ }^{74}$ This

OProfessor Mark Roe writes that the Presidents' Council of the keiretsu is an informal mechanism for stockholder influence. See MARKJ. ROE, STRONG MANAGERS, WEAK OWNERS 179 (1994). It is a plausible speculation because the aggregate voting power of the company presidents attending the President Council constitutes around $20 \%$ of each company. If the presidents agree, they could decide anything they want. In fact, the Presidents' Council does not play such a decisionmaking role, but plays the role of keeping the reputation of their group name, i.e., brand management.

TNissei TohshiKenkyuhkai(JapanLife Insurance Workshop on Investment), Senryakuteki Shohken Tohshi (Tactical Stock Investment) 85 (1980).

${ }^{21}$ That is the reason why most of Mr. Pickens' requests were rejected outright by Koito's management. See supra note 1 and accompanying text.

${ }^{72}$ The managing unit is the minimum unit in the company, whose performance is independently evaluated by the monitor, not only on the flow level, but also on the stock level. They are usually recognized as in-house divisions.

${ }^{7}$ Spin-off is the general term used to refer to corporate divisions, that is, the separation of a corporation into plural corporations, not only on an asset level, but also on a shareholder level. The corporate division can legally be categorized into three types: spin-off, split-off, and split-up, depending upon the way of dividing corporation. See MEL VIN A. EISENBERG, THE STRUCTURE OF THECORPORATION267(1976). Several statistical studies show that the spin-off has a positive effect on market price of the stock in the U.S. See, e.g., Gailen Hite \& James Owers, Security Price Reactions Around Corporate Spin-off Announcements, 12 J. Fin. EcoN. 409 (1983); James Miles \& James Rosenfeld, The Effect of Voluntary Spin-off Announcements on Shareholder Wealth, 38 J. FiN. 1597, 1598 (1983); Katherine Schipper \& Abbie Smith, Effects of Recontracting on Shareholder Wealth: The Case of Voluntary Spin-Offs, 12 J. Fin. EcoN. 437 (1983).

${ }^{74}$ The spin-off has almostnever been used in Japan, partly because it is a taxable transaction but also because it is ambiguous whether the spin-off is legally effective. (The special procedures of corporate division were just enacted in May 2000.) The biggestreason, however, is that Japanese management could not imagine dividing the Company Community. 
practice removes the distinction between a market and a hierarchical solution. The American practice, however, remains polar. ${ }^{75}$ For example, in Japan a division may be "spun-off" to form a separate company (subsidiary) yet these two companies will remain connected by the parent firm's equity stake in the spin-off firm.

In Japan, wholly-owned subsidiaries often have the unique ability to use delegated authority. In the United States, from a govemance point of view, there is no distinction between an in-house division and a whollyowned subsidiary. ${ }^{76}$ In Japan, the wholly-owned subsidiaries are recognized as having more autonomy than in-house divisions. Japanese companies maintain headquarter managers who often create wholly-owned subsidiaries for the purpose of signaling autonomy. Although the precise reason for such a business practice needs further study, ${ }^{77}$ it is apparent that the practice is based on a Japanese social norm of respecting the firm as a legal entity. This social norm also works in the context of the Company Community for creating "companyism."78

Although limited in Japan, free competition markets play an important role in keeping the Japanese system efficient. The competition in the product market for consumers and that in foreign countries provides the Company Community with the incentive to create efficient production systems. The price indication by the capital market concerning outside shareholders and bondholders also monitors Japanese corporate efficiency. ${ }^{79}$ As stated previously, outside shareholders do not have a voice in Japanese corporate governance, but maintain the ability to monitor management by exit. $^{80}$

The existence of separate, organized capital and product markets is the most distinguishing characteristic of the overall Japanese market. This system of organized markets is generally referred to by the term of keireisu.

${ }^{75}$ See OLIVER E. WILLIAMSON, MARKETS AND HIERARChIES (1975).

${ }^{26}$ In the United States, wholly-owned subsidiaries are created either for regulatory purposes or purposes of limiting liability.

" See Hideshi Itoh \& Zenichi Shishido, The Firm as a Legal Entity: Its Importance and Implications for Corporate Restructuring in Japan (Working Paper, 1999).

${ }^{73}$ See infra note 113 and accompanying text.

${ }^{79} \mathrm{~A}$ recent phenomenon in Japan is that rating companies play an important role as a monitor. See Big Decrease of Issuing Common Corporate Bond: Companies are More Selected by Reputation, NIKKEl, Sept. 17, 1998, at 1 (Japan).

Stock prices statistically relate to management tumover. See generally Steven Kaplan, Top Executive Rewards and Firm Performance: A Comparison of Japan and the U.S., 102 J.PoL. ECON. 510 (1994) (recognizing the comelation between executive umover and corporate earnings).

${ }^{81}$ The term "leiretsu" carries many different interpretations and is thereby prone to misunderstanding. For this reason, the term "organized mariket" will be used throughout the remainder of the article. 
There are two different forms of keiretsu - vertical and horizontal. Essentially, vertical keiretsu is a form of vertical integration, examples of which are Toyota and Hitachi. Horizontal keiretsu, on the other hand, is simply a cross-shareholding group of firms, for example, Mitsubishi and Sumitomo. In the United States, the typical misunderstanding of keiretsu considers the horizontal keiretsu as having a substantial existence on its own, rather than as a collection of individual firms, each maintaining separate existence and functions. 22

The organized market consists of long-term relational transactions, rather than spot transactions. Most transactions between firms of both product and finance are made in the organized market. Transacting firms often hold stocks in each other (cross-shareholding) in order to guarantee long-term transactions. ${ }^{83}$ Therefore, the decision to continue or terminate their relationship must be made from the viewpoint of the "total transaction" which includes the product transaction as well as the equity transaction. ${ }^{84}$ Trading partner firms, as inside shareholders, potentially may have some voice in a crisis where the Company Community is unable to solve the problem unilaterally. The main bank is the most influential of these. ${ }^{85}$ It is not clear whether the inside shareholder's role as monitor is performed under the duties of a shareholder or of a trading partner.

The external labor market and the corporate control market are very incomplete in Japan. Once an employee obtains a job in a firm, changing firms will result in losing his position of seniority in the Company Community and also damage to his reputation. The unwillingness of Corporate Community employees to readily change communities has created a stagnant external labor market. ${ }^{86}$ This phenomenon has had both a positive and negative effect on corporate governance. The lack of the external labor market is the premise behind the Company Community, creating "locked-in" incentives for employees to monitor management, so as to protect each individual employee's stake in the corporation. It also forces shareholders to rely on the existing work force, which creates the shareholders' commitment to the lifetime employment. The absence of an external labor market has, however, led the Japanese labor market to a rather dysfunctional

"See supra note 69 and accompanying text.

${ }^{3}$ The social norm of valuing the long-term relationship is also observed in the labormanagement relationship. See supra note 65 and accompanying text.

"See Paul Sheard, Interlocking Shareholding and Corporate Governance, in THE JAPANESE FIRM: THE SOURCE OF COMPETIITVE STRENGTH 310 (Masahiko Aoki \& Ronald Dore eds., 1994).

ss See Masahiko Aoki et al, The Japanese Main Bank System: An Introductory Overview, in The Japanese MaIn Bank System 3 (Masahiko Aoki \& Hugh Patrick eds., 1994).

${ }^{26}$ See Gilson \& Roe, supra note 66, at 531. 
competition within the corporate governance structure for promotion and other non-economic benefits.

The corporate control market, like the external labor market, is nonexistent. Hostile takeovers in Japan have rarely succeeded, for the majority stocks in a publicly traded company are stabilized by cross-shareholding measures. The existence of a Japanese social norm labeling hostile takeovers as nearly criminal activity also places limits on the use of this mechanism. ${ }^{87}$ Recently, however, there have been signs of change in the corporate control market. Weaknesses in some cross-shareholding arrangements have been observed where members of the cross-shareholding group have sold shares to avoid further losses in the capital markets.

\section{Monitoring Management}

Contrary to the basic legal model of the corporation, in Japanese corporate practice, management is monitored neither by the board of directors as an agent of shareholders nor by hostile takeovers. Instead, the monitoring of a Japanese corporation is performed in three different stages. The first stage is the in-house monitoring conducted by the Company Community. The second stage of monitoring is done by the inside shareholders. ${ }^{88}$ Third, an outside shareholder, although having no voice, may monitor management by exit. In this capacity, the outside shareholders serve as a potential third stage monitor. ${ }^{89}$

Ideally, each member of the Company Community monitors management through their participation in the Community. If the performance of the firm, revealed in the product market and the stock market, is poor, management turnover will take place solely within the Company Community. Ideally such tumover will occur by the voluntary resignation of the responsible management. ${ }^{90}$ Pressures from within the

\footnotetext{
${ }^{87}$ Such social norms may, however, be very fragile. The social norm in the U.S. was also strongly antihostile takeover until the late 1960 s or early 1970 s when a major investment banker made substantial profits from a hostile takeover. Shortly thereafter the social norm began to recede. For more on the influence of social norms on corporate law systems, see Melvin A. Eisenberg, Corporate Law and Social Norms, 99 CoLUM. L. Rev. 1253, 1288 (1999).

${ }^{88}$ The Japanese model is not the "interactive" corporate govemance model, but the "interdependent" corporate governance model, where the monitoring function is delegated to some stakeholder. Only at the stage of real crisis does the interactive model take place. See, e.g., George G. Triantis \& Ronald J. Daniels, The Role of Debt in Interactive Corporate Governance, 83 CAL. L. REV. 1073, 1106 (1995).

${ }^{5}$ There is some empirical evidence for this monitoring capacity in that the stock prices in Japan are statistically comrelated to management turnover. See Kaplan, supra note 80, at 523 .

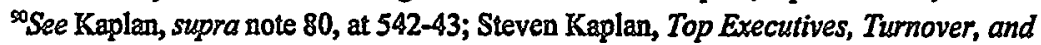
Firm Performance in Germany, 10 J.L. ECON. \& ORG. 142 (1994). According to Steven Kaplan's statistical studies, the relationship between management tumover and firm performance in Japan is
} 
Company Community reinforce this voluntary action. As long as such monitoring within the Company Community works well, it is not necessary for shareholders to intervene in the governance of the Company Community. The members of the Company Community have the incentive to maintain good performance within the corporation to avoid the intervention by shareholders. In the event that monitoring within the Company Community is ineffective, the inside shareholder, particularly the main bank, will intervene as the second stage monitor. ${ }^{91}$

\section{JAPANESE SOLUTIONS TO THE HIDDEN PROBLEMS OF CORPORATE LAW}

The previous two Parts demonstrated that, while the Japanese legal system is based on shareholders' ownership, the Japanese corporate practice more closely resembles employees' ownership. In this Part, a reason for this paradox, given from the perspective of the hidden problems of corporate law, will be presented.

The legal system of the corporation, which is based on shareholder ownership, is congruent with the economic concept of efficiency. Corporate law, however, leaves unresolved two important problems. First, is how to balance the monitoring and the autonomy of the management. Second, is how to balance the human capital and the money capital. Any developed corporate system has its own scheme to solve these two problems.

\section{A. Stabilizing Management by Cross-Shareholding}

Although monitoring management is indispensable, too much instability in the management position distorts managerial incentives. ${ }^{92}$ Any reasonable person will hesitate to make relation-specific investments if his management's position is fragile and will also have no incentive to initiate long-term projects. Management requires autonomy in order to stimulate 
their incentives. ${ }^{93}$ It is still unresolved, however, how a corporation may balance the monitoring and the autonomy of the management.

Hostile takeovers are viewed as a straight expression of shareholder ownership because shareholders directly replace management. This raises a difficult question - In what manner should the law permit incumbent management to defend against hostile takeover attempts? The simple answer from the basics of shareholder ownership is that the law should not allow any defense at all. It is not the incumbent management but the shareholders who should choose the next management. ${ }^{\text {st }}$

Even in the United States, most experts do not take such an extreme position, but are forced to take a somewhat balanced position between shareholder ownership and a stabilized management. ${ }^{95}$ American courts are agreeable to varieties of poison pills, ${ }^{96}$ and most states have antitakeover statures. ${ }^{97}$ Stakeholder statutes are another phenomenon that demonstrate that state legislatures are becoming favorable to management stabilization. ${ }^{93}$ Today, American management is much more insulated from the threat of hostile takeovers than in the 1980s. 9

The Japanese method of stabilizing management is through crossshareholding. An implicit agreement is made between two companies to hold ownership in the other partners' stock, usually around one percent by

${ }^{93}$ Professors Daines and Klausner show an interesting statistic that most initial public offering (IPO) companies have antitakeover provisions even though their shareholders are sophisticated institutional investors, such as venture capitals. They present the enigma of why such sophisticated shareholders, who are usually controlling shareholders at the IPO, allow the management to choose charter provisions that statistically have a negative impact on the stock price. This data is not necessarily enigmatic. From the point of view of this article, it is quite natural for sophisticared shareholders to understand the necessity of management stability, particularly for the starbugs thes require potentially large relation specific investments from the management. See Robent Daines \& Michael Klausner, Value-Maximizing Charters: Antitakeover Provisions in IPOs 17 (Working Paper, N.Y.U. Law School, 1998).

see Zenichi Shishido, Corporate Takeovers in Japan, in JAPAN SecurttIes ReSEARCH INSTITUTE, CAPITAL MARKETS AND FINANCIAL SERVICES IN JAPAN: REGULATION AND PRACTICE 129 (1992).

${ }^{83}$ See AMERICANLAWINSTITUTE, PRINCIPLES OF CORPORATE GOVERNANCE: ANALYSIS AND RECOMMENDATIONS $\S 6.02$ (1994).

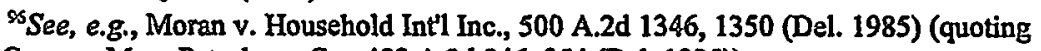
Unocal Corp. v. Mesa Petroleum Co., 493 A.2d 946, 954 (Del. 1985)).

${ }^{97}$ See supra note 43 and accompanying text (surveying various antitakeover statutes).

${ }^{53}$ See supra note 48 and accompanying text (explaining how the competing interests of stakeholders and shareholders can be balanced).

Because of the difficulties of hostile takeovers, the proxy fight is now becoming the main batulefield. See Steven M. Bainbridge, Redirecting State Takeover Laws at Proxy Contests, 1992 WIS. L. REV. 1071. 
nonfinancial firms and up to five percent by banks. ${ }^{100}$ Each company makes the same type of implicit agreements with, for example, twenty companies. Consequently, a spider web of mutual stockholding among inside shareholders is created, thereby stabilizing majority stock ownership. ${ }^{101}$

An advantage of cross-shareholding, as opposed to poison pills and antitakeover statutes, is that the corporation remains in control by the financial market. Cross-shareholding further implies costs. If a company's performance is so poor that cross-shareholding partners consider it not worth holding, even from the "total transaction" point of view, they will sell that company's stock. ${ }^{102}$

As mentioned in Part II, the difference between the corporate law of Japan and the United States may have led to the different management stabilization schemes. ${ }^{103}$ American corporate law is basically enabling law, which is flexible enough to allow shareholders (actually management) to tailor legal governance structure to be more evasive of hostile takeovers. Conversely, Japanese corporate law, that is basically mandatory law, is very loyal to the principle of stock majority. Japanese corporate law leaves little room for the legal arrangement of stabilizing management. Thus, Japanese corporate governance was forced to find different avenues of protection from hostile takeovers, including that of cross-shareholding.

\section{B. Employees as Quasi-Residual Claimants}

It goes without saying that you not only must employ money capital but also human capital to run a business. No corporation may become successful with the world market without adequate motivation of its management and employees. Corporate law, however, speaks nothing of how to give human capital providers incentives to make those relation specific investments that contribute most to the profitability of the firm.

${ }^{100}$ While American banks may not hold shares of other companies for investment purposes (Glass-Steagall Act of June 16, 1933, ch. 89, 48 Stat. 162), Japanese banks can own up to five percent (Securities and Exchange Act, $\S 65$; Anti-Monopoly Law, $\S 11$ ). This is an important distinction of the legal systems, which contributes to the differences in corporate governance practices. See Rog, supra note 69, at 95, 169. The Anti-Monopoly Law also puts five percent limits on securities firms and ten percent limits on insurance companies (Anti-Monopoly Law, § 11).

${ }^{101}$ But see Ramseyer, supra note 4, at 546 (expressing skepticism about the effect of crossshareholding as an anti takeover measure).

${ }^{102}$ See supra text accompanying note 84. The aggregate percentage of publicly traded shares held in cross-shareholding (number of stock base) dropped more than 3\% to $15.39 \%$ between 1990 and 1998. The stable shareholding rate dropped more than $7.5 \%$ to $38.22 \%$ during the same period. Statistics by Nissei Kiso Kenkyuhsho (Japan Life Insurance Basic Research Institute) (1999). See Figure 6.

${ }^{103}$ See supra notes 38-44 and accompanying text (comparing Japanese management stabilizing schemes with their American counterparts). 
Stock options, management buyouts (MBO), ${ }^{104}$ and employee stock ownership plans (ESOP) are American efforts to give managers and employees such incentives. ${ }^{105}$ Furthermore, Silicon Valley firms engage in an interesting practice to balance human capital and money capital. For example, a usual equity arrangement in Silicon Valley is that just after creating a corporation among entrepreneurs who invested $\$ 0.10$ per share of common stock, venture capitalists invest $\$ 2.00$ per voting preferred stock which is convertible to a common stock. ${ }^{105}$

The Japanese answer to this question makes employees quasi-residual claimants, without making them shareholders. Most Japanese companies pay stable dividends to their shareholders regardless of the amount of profit ${ }^{107}$ and pay their employees bonuses, which further reflect the profitability of the company. ${ }^{108}$ Furthermore, a particular company's success will lead to a change of social status for members of their Company Community.

The success of the Japanese method of motivating management and employees should be attributed to more than just an economic explanation. The feeling of attachment to the Company Community provides management and employees with an ethos of working hard for the sake of the company itself.

An interesting analogy may be made to Max Weber's famous study on the relationship between Protestantism and capitalism. ${ }^{109}$ Weber points out the paradox that although Protestantism, Calvinism in particular, appears

${ }^{104}$ See Roberta Romano, A Guide to Takeovers: Theory, Evidence, and Regulation, 9 Y ALE J. ONREG. 119, 133 (1992) (explaining how MBOs have the effect of increasing productivity since management has an ownership interest).

${ }^{105}$ See Kevin Murphy, Executive Compensation, in 3B HANDBOOK OF LABOR ECONOMics 2485 (Orley Ashenfelter \& David Card eds., 1999).

${ }^{105}$ See Michael J. Halloran et al., Venture Capital and Public Offering NEGOTIATION 6-4 (3d ed. 1997).

${ }^{10}$ The payment of a stable dividend to shareholders, particularly when this dividend does not vary significantly over time, combined with the lack of hostile takeovers, may lead one to the conclusion that Japanese corporate shares are simply preferred shares and therefore investors should be willing to pay only the present value of the dividend stream the share(s) represent. As a corollary, Japanese share prices should not reflect the underlying value of firms. It is possible that outside shareholders will have an expectation of an "enlarged pie" in the end. These expectations were thwarted, however, after the crash of the "bubble" and shareholders failed to realize gains from the enlarged pie. Further, the distribution of new shares to current shareholders with no new investment required, which has been Japanese practice since the early 1970s, may to some extent tie share price to profitability by increasing dividends over time.

${ }^{103} \mathrm{An}$ analogy can be made here with workers' cooperatives, where workers receive a relatively small amount of fixed salary at the outset, but will receive the residual later. See HANSMANN, supra note 9, at 13. trans., 1930).

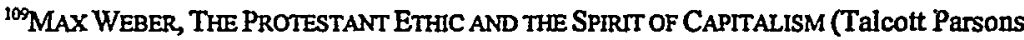


anti-capitalistic, the Protestant Asceticism created an indispensable force for modern capitalism. Weber states, "[T]he psychological sanction of it through the conception on this labor as a calling, as the best, often in the last analysis the only means of attaining certainty of grace." although the concept of Company Community in the Japanese model appears to be anti-shareholder, it created the psychological sanctions which make management and employees, including blue-collar workers, work "as if it were an absolute end in itself."'111 At the very least, Japanese workers' attitudes are in opposition to "continual calculations of how the customary wage may be earned with maximum of comfort and a minimum of exertion." ${ }^{\text {"112 }}$ As a consequence, the Company Community contributed to the creation one of the most productive business systems in the world, benefiting, quite centrally, the shareholder.

Employees exercise an element of control through membership in the Company Community. Management is elected based on an informal consensus of the employees. In other words, the top of the Company Community doubles as the CEO of the company. This consensus is established not through any formal involvement of the employees in the management selection process, but through the long-term process in which employees are continually selected for promotion by the informal consent of fellow employees. This gives informal or implicit voting rights to the employees over which some will become management. This gives the employees of a Japanese firm both a quasi-residual claim and a quasiresidual right of control. In this sense, Japanese employees may be quasiowners of firms.

Employees, however, receive no formal elements of control from their status as a quasi-residual claimant. While receiving no formal rights of control, the institution of the Company Community gives employees substantial informal elements of control. Lifetime tenure of employees and the lack of an external labor market are two of the factors forcing shareholders to commit to granting employees some implicit control rights. These factors combine to limit the substitutability of core employees in the Japanese firm, thus forcing commitment.

The Company Community is not only similar to employee owned firms, but also solves inherent problems usually found in employee ownership, through combination with "companyism." Increasing the size and social importance of the company is an incentive common to members

${ }^{110} I d$. at 178.

"III. at 62 .

${ }^{112} I d$. at 61-62. 
of the Japanese Company Community ("Companyism"). ${ }^{113}$ The notion of "companyism" decreases the diversity of interests among those controlling the firm, making collective action problems less likely to occur. Surprisingly, Companyism not only solves the collective action problem, but also solves the horizon problem. Normally, employee-owned firms have little incentive to invest in long-term projects because of employees' lack of transferable residual claims. ${ }^{114}$ In Japanese companies, it is not the shareholders but the employees that are eager to invest in long-term projects benefitting the future of the company.

\section{SHAREHOLDER OWNERSHIP AS THE END GAME NORM AND RECENT PHENOMENA}

\section{A. Employee Ownership?}

Many observers of Japanese corporate govemance consider Japanese companies, at a practical level, to be owned by the employees and not the shareholders. ${ }^{115}$ But this is not as true as it may seem. The shareholders of Japanese companies leave employees as the quasi-residual claimants in order to give them proper incentives.

Often, however, severe conflicting interests between shareholders and employees occur, triggering shareholders to use their control to force management to give shareholder interests priority. Both in the United States and in Japan, negative corporate income and the long term decline of stock prices trigger the shareholder ownership end game norm. ${ }^{116}$

Generally speaking, in long-term contractual relationships, the "relationship preserving norm," such as merchant customs, works as long as there remains a working relationship between the parties. Once, however, the relationship turns sour, and the parties consider terminating their relationship, the "end game norm," such as written contracts and laws, is

${ }^{113}$ During the economic growth era, shareholders also hrd these incentives. After the recent economic downturn, shareholders and members of the Company Community may no longer share such incentives. In such a period, shareholders are likely to prefer receiving a dividend over firm growth in size or importance.

${ }^{114}$ See HANSMANN, supra note 9, at 79.

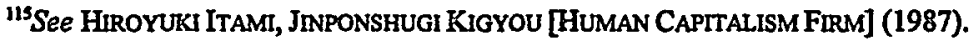

"Kaplan, supra note 80, at 530-31 (illustrating the correlation of negetive corporate income and stock price decline). See also Yukiko Abe, Chief Execustive Tumover and Firm Performance in Japan, 11 J. JAPANESE \& INT'L ECON. 2, 19 (1997). But see Hideali Miyajima, Presidential Tumover and Performance in the Japanese Firm: The Evolution and Change of the Contingent Govemance Structure under Main Bank System, in JAPANESEMANAGEMENT IN THE LOW GROWTH ERA 121 (Daniel Dirks et al. eds., 1998). 
expected to prevail. ${ }^{117}$ The same is true in the relationship between money capital providers and human capital providers in the corporation. In Japanese corporate governance, while "employee ownership" is the relationship preserving norm, shareholder ownership is the end game norm. ${ }^{118}$

The form of the end game in Japan is also different than in the United States, where the end game takes on a formal presence, such as hostile takeovers and management dismissal by the board. In Japan, the end game consists of inside shareholders exercising their voice in the corporation and outside shareholders selling off their shares in a poorly performing corporation. Through these mechanisms, shareholders in Japanese corporations force management to grant shareholder interests priority and replace the management not following such a norm.

The circumstances required to force such an end game situation may be quite dramatic, however, still occurred during the recent and ongoing Japanese recession. The importance of the end game norm, that makes the Japanese system efficient, is apparent when compared to the former employee owned firms in East European countries and their struggle to private process. ${ }^{119}$

\section{B. Emergence of the Real Owners in Recession}

During the economic growth era, most stakeholders of Japanese companies shared interests in enlarging the scale of the company and its market share. To accomplish this goal, it was in the shareholders' interest to let employees act as the quasi-residual claimant. Conflicts, of course, always arise when dealing with multiple parties with differing backgrounds and methods of operation. Even though most stakeholders were interested in enlarging the company during the growth era, conflicts still arose. The Japanese Company Community motivated their members to set aside their differences in order to harmonize the interests of members toward the same goal. In essence, during the growth era, the Japanese corporate governance system may have produced more company growth than was otherwise achievable by mitigating conflicts of interest between stakeholders.

\footnotetext{
${ }^{117}$ See Lisa Bemstein, Merchant Law in a Merchant Court: Rethinking the Code's Search for Immanent Business Norms, 144 U. PA. L. REV. 1765, 1796 (1996).

${ }^{118}$ Even in the United States, shareholder ownership is not necessarily the relationship preserving norm. Some experts observed that shareholders' voting power is nominal in publicly held corporations and management does not always try to maximize shareholders' interest but rather balances the interests of many stakeholders. See Blair \& Stout, supra note 11, at 310.

119.9e generally 1-2 ROMAN FRYDMAN ET AL., CORPORATE GOVERNANCE IN CENTRAL EUROPE AND RUSSIA (1996).
} 
During the recession era, however, many more significant conflicts of interest emerged. One such conflict was how to decrease the workforce and how to use the free cash flow. ${ }^{120}$ Such conflicts threatened to put stakeholders' individual interests sharply at odds with one another, for the nature of this situation as a zero sum game is to use one group's gains from reorganization to offset another's losses. In this situation, shareholders will emerge as the real owner of the company and force management to run the business for their own best interests.

Outside shareholders have no voice in Japanese corporate governance, but they could monitor management by exit. Considering the recent financial crisis in Japan, one now can readily observe the Japanese stock market's emergence as a monitor of Japanese corporations. Therefore, the distinction between inside and outside shareholders is further blurred. ${ }^{121}$ The stock market has increasingly given signals to management necessitating worker lay offs or management resignations. ${ }^{122}$ In this sense, the real owners of Japanese corporations can be said to be the shareholders.

One may wonder why management would ever obey signals given by outside shareholders, since they have limited control over the management. The answer lies in the fact that companies must receive financing from both equity and debt markets. This financing becomes critical in a recessionary period. New equity financing through the stock market becomes difficult when shareholders are selling off company shares. More importantly is the fact that bank financing to corporations is linked to corporate performance in equity markets. Therefore, outside shareholders may effectively exercise their monitoring power in the corporate governance through their ability to exit by selling off corporate shares.

Management of a corporation with a declining stock price may resign due to the management's perceived fiduciary duty to workers and shareholders. The Company Community tends to select management who perceive this fiduciary duty and further allow easy withdrawal of a possibly problematic management, through their own sense of moral obligation. Cross-shareholders may also place pressure on poorly performing managers to resign. Through these dual pressures, management responsible for poor

\footnotetext{
${ }^{220}$ See Ronald J. Gilson \& Mark J. Roe, Understanding the Japanese Keiretsu: Overlaps Between Corporate Governance and Industrial Organization, 102 YALE L.J. 871, 881 (1993).

${ }^{121}$ Also, now in Japan, particularly at the stage of crisis of a company, the phenomenon of "interactive" monitoring among banks, trading parmers, bond holders, and shareholders can be observed. See Triantis \& Daniels, supra note 88, at 1073.

${ }^{12}$ Pressures from the Japanese stockmarket have aiready forced some firms to restructure their labor practices. NIKKEl, Apr. 23, 1999, at 5 (Japan). The stockmarket has also been signaling the substantive adequacy of these restructurings, reflecting success in higher stock prices. NIKKEI, Mar. 9, 1999, at 1 (Japan).
} 
stock performance resign in a fashion conducive to a smooth transition to a more formidable management.

Outside shareholders are also gaining more voice through shareholder derivative actions. The decrease of the filing fee for shareholder derivative actions has doubled the number of suits changing the mentality of small shareholders in Japan. ${ }^{123}$ Today, the shareholder derivative action is a hot issue and has had a significant impact on Japanese corporate governance. ${ }^{124}$ Japanese management is becoming more careful in making business decisions that conflict with shareholder interests. For example, today it is more difficult for the main bank to intervene in rescuing a client company from trouble, because, while such a rescue may be in the long-term interest of the company or bank, it may be opposed to the short-term interests of shareholders. ${ }^{125}$

During the current Japanese recession, we may also observe the emergence of two incomplete markets: the external labor market and the corporate control market. Company lay-offs and corporate bankruptcies have taken away the job stability employees once enjoyed. This has also caused many employees who still have their jobs to lose their loyalty to the Company Community. Yet, firms have become more positive about acquiring people who show their ability at other firms. The recession has further caused firms with poor performance to be unable to maintain crossshareholding. ${ }^{126}$ A possibility remains that the corporate control market will emerge. The development of these two markets will inevitably affect the future of the Company Community. ${ }^{127}$

\section{CONVERGENCE DEBATES AND THE FUTURE OF JAPANESE CORPORATE GOVERNANCE}

In the previous section, the effect of the recession in moving shareholders from the back bench to the front bench was considered. Japanese corporate governance thereby appears to be changing towards the American way. Will the Japanese corporate governance system simply

\footnotetext{
${ }^{123}$ See supra note 34 and accompanying text (discussing the decreasing costs of litigation for shareholders).

${ }^{124}$ See Kanda, supra note 54, at 189.

${ }^{123}$ In the bankruptcy of Yamaichi Securities Firm, for example, Fuji Bank, the main bank of Yamaichi, refused to rescue a client company partly because of the fear of being sued by shareholders. See NIKKEI, Dec. 2, 1999, at 5 (evening version) (Japan).

${ }^{126}$ See supra note 102 and accompanying text (noting the decline in shares held in crossshareholding).

${ }^{127}$ See Milhaupt, supra note 17 , at 47 , for a detailed study of recent phenomena.
} 
converge with the American system? This question will be considered in the following section.

\section{A. Criteria of Convergence}

The debate on the convergence of corporate governance is an interesting recent phenomenon. ${ }^{128}$ This debate centers on whether world corporate governance systems will ever converge to a single optimal system or maintain their distinctive features. Roughly speaking, there are three schools of thought on the issue. The first school argues that there is one optimal governance system and that economic institutions will lead world corporate governance systems to converge into this optimal system. ${ }^{129}$ The second school predicts that although a single optimal system exists, convergence cannot be expected because of significant transactional costs involved in changing corporate governance institutions, which arise from cultural differences among countries and domestic political frictions. ${ }^{130}$ The third school suggests that the search for one "true" corporate governance system will be a failed endeavor for there is not a single optimal system, but multiple equilibria. ${ }^{131}$ Under this view, convergence may not occur.

More than simply the differences in the conclusions of the three schools, there are significant analytical difficulties to engaging in such convergence devates. The biggest difficulty concems the criteria adopted by each school for the measure of convergence. The convergence debates primarily utilize three different criteria: dispersed stock ownership versus concentrated stock ownership, ${ }^{132}$ capital market centered monitoring versus bank oriented monitoring, ${ }^{133}$ and common law regime versus civil law regime. ${ }^{134}$ Comparisons of the interrelations among these criteria are used to make inferences on the convergence question. Common law countries generally have stronger protections for minority shareholders, which lead to dispersed ownership. ${ }^{135}$ Dispersed ownership is the foundation of the capital market centered monitor, i.e., that hostile takeovers will replace poor

${ }^{12}$ See supra note 4. The topic of the Corporate Law panel, chaired by Melvin A. Eisenberg, at the 1999 meeting of American Association of Law Schools focused on this issue entirely. Columbia law School has been a leader in this area with the Sloan Project on Corporate Govemance, which in 1997 held a major conference on this topic as well.

${ }^{129}$ See Ramseyer, supra note 4, at 558.

${ }^{130}$ See Bebchuk \& Roe, supra note 4, at 169.

${ }^{131}$ See Gilson, supra note 4, at 19.

${ }^{132}$ See Bebchul \& Roe, supra note 4, at 133; Coffee, supra note 4, at 642.

${ }^{133}$ See Gilson, supra note 4, at 11.

${ }^{134}$ See La Porta et al., supra note 20, at 1132; Coffee, supra note 4, at 644.

${ }^{135}$ See Coffee, supra note 4 , at 644. 
management. These criteria are, however, both ambiguous and insignificant. Japanese corporate governance is a good example that illustrates the shortcomings of the above approach.

Japan, although a civil law country, has at the same time been influenced by American law since the end of the Second World War. ${ }^{136}$ Japanese corporate law is an interesting mixture of German law, American law, and original Japanese ideas. The distinction between civil law and common law basically focuses on the procedural system, and does not necessarily lead to different protections of minority shareholders. Japanese corporate law is, as was shown in Part II, no less protective of minority shareholders than American corporate law. ${ }^{137}$

Whether the Japanese stock ownership structure may categorized dispersed or concentrated is another question. ${ }^{138}$ If one looks at the number of shareholders and ownership stakes of Japanese publicly held corporations, the stock ownership appears rather dispersed. ${ }^{139}$ Most participants of the convergence debates would, however, categorize Japan as having concentrated ownership because majority stock ownership is stabilized through cross-shareholding. If this is the correct view, then the real criterion should be to consider the difficulty for a raider to perform a successful hostile takeover. If the criterion also evaluates the monitoring voice of shareholders, American institutional investors today may have a stronger voice than their Japanese counterpart.

The second criterion, capital market centered monitoring versus bank oriented monitoring, then becomes both obvious and significant. This is, howeover, also not necessarily true. Although the main bank has been

\section{4 (1973).}

136See, e.g., DAN FENNO HENDERSON, FoREIGN ENTERPRISE IN JAPAN: LAWS AND POLICIES

${ }^{15}$ See supra notes 21-37 and accompanying text (comparing shareholder protection of Japanese law to that of American law). If we take securities regulations into consideration, however, stronger enforcement of the insider trading prohibition in the United States could be counted as a stronger protection of minority shareholders.

${ }^{138}$ The debate over problems with dispersed versus concentrated ownership and their solutions originated largely with ADOLPH BERLE\& GARDINI MEANS, THE MODERN CORPORATION AŃD PRIVATE PROPERTY (1932). See Eugene Fama \& Michael Jensen, Separation of Ownership and Control, 26 J. LAW \& ECON. 301, 304-05 (1983) (discussing how to control the downside of dispersed shareholder ownership while maximizing the benefits of shareholder ownership and risk bearing). See also Mark J. Roe, A Political Theory of American Corporate Finance, 91 CoLUM. L. REV. 10, 33-53 (1991) (discussing the political forces that drive corporate and shareholder structure).

${ }^{13}$ The top five owners of Japanese copporations own collectively $33 \%$ as opposed to $25 \%$ in the U.S. and $41.5 \%$ in Germany. See Stephen Prowse, Corporate Governance in an International Perspective: A Survey of Corporate Control Mechanisms among Large Firms in the U.S., U.K., Japan and Germany, 4 FIN. MARKETS, INSTTUUTONS AND INSTRUMENTS 1, 23-25 (1995). 
playing an important monitoring role in Japanese corporate governance, ${ }^{140}$ the capital market has also been an important monitor. Management turnover and stock price are statistically correlated. ${ }^{141}$ There have always been quasi-hostile takeovers, in which management is forced to agree to being merged. In this current situation of financial crisis, most observers would hesitate to categorize Japanese corporate governance as having bank oriented monitoring. ${ }^{142}$ Japanese banks' monitoring capacity is getting weaker and the weight of the capital market as a monitor is getting heavier. ${ }^{143}$ It is no longer true that American corporate governance symbolizes capital market centered monitoring. ${ }^{144}$ Because of the development of poison pills and anti-hostile takeover statutes, ${ }^{145}$ real hostile takeovers are now rather rare. ${ }^{146}$ Instead of hostile takeovers, institutional investors ${ }^{147}$ and independent directors ${ }^{148}$ are currently more significant monitors in the United States.

From the viewpoint of corporate governance, the issues of whether ownership structure is dispersed or concentrated, and whether monitoring is capital market centered or bank oriented are not substantial points. The important point that must be raised as the criterion of an efficient corporate governance system is balancing between the monitoring and the autonomy

\footnotetext{
${ }^{160}$ Some observers argue that the role of the main banks has been exaggerated. See TosHIRO MiWA, FirmS AND INDUSTRIAL ORGANIZATION IN JAPAN 120-22 (1996).

${ }^{141}$ See Kaplan, supra note 80 (giving empirical validation to the correlation between corporate eamings and executive turnover).

${ }^{142} \mathrm{~A}$ recent editorial in the Japanese newspaper Nilkcei claims that the Japanese main bank system no longer works, citing the fact that Nissan's main bank was not consulted by Nissan on the alliance between Nissan and Daimler/Chrysler. Nikkei, May 9, 1999, at 7 (Japan).

${ }^{143}$ See Watanabe \& Yamamoto, supra note 2, at 12 (recognizing that bank loans are no longer a dominant source of financing for Japanese companies). See Figure 7.

${ }^{14}$ For a better understanding of capital market centered monitoring, see Michael Jensen, Takeovers: Their Causes and Consequences, 2 J. ECON. PERSP. 21, 23 (1988); Henry G. Manne, Mergers and the Market for Corporate Control, 73 J. PoL. EcoN. 110, 112 (1965); Richard Roll, Empirical Evidence on Takeover Activity and Shareholder Wealth, in KNIGHTS, RAIDERS, AND TARGETS: THE IMPACT OF THE HOSTHE TAKEOVER 241-52 (John C. Coffee, Jr. et al. eds., 1988). ${ }^{145}$ See Martin Lipton, Corporate Governance in the Age of Finance Corporatism, $136 \mathrm{U}$. PA. L. REv. 1, 30 (1987); Romano, supra note 43.

${ }^{116}$ See JeSSE CHOPER ET AL., CASES AND MATERIALS ON CORPORATIONS $895-935$ (1995).

${ }^{147}$ See Bernard Black, Agents Watching Agents: The Promise of Institutional Investor Voice, 39 UCLA L. REv. 811, 826-27 (1992); John C. Coffee, Jr., Liquidity Versus Control: The Institutional Investor as Corporate Monitor, 91 CoLuM. L. REv. 1277, 1340 (1991); Roberta Romano, Public Pension Fund Activism in Corporate Governance Reconsidered, 93 ColuM: L. REV. 795, 798 (1993).

${ }^{148}$ See Benjamin E. Hermalin \& Michael S. Weisbach, Endogenously Chosen Boards of Directors and Their Monitoring of the CEO, 88 AM. ECON. REV. 96, 97 (1998); Laura Lin, The Effectiveness of Outside Directors as a Corporate Governance Mechanism: Theories and Evidence, 90 Nw. U. L. REV. 898, 911 (1996); Roberta Romano, Corporate Law and Corporate Governance, 5 INDUS. \& CORP. CHANGE 277, 279-97 (1996).
} 
of management, or in other words, the degree of stability of the management position. ${ }^{149}$ In this functional sense, the corporate governance systems have already converged, at least within the United States, Japan, and Germany. ${ }^{150}$

As a formal convergence theory, it is more useful to argue what basics must be shared by any efficient corporate governance system. These basics are shareholder ownership as the end game norm, ${ }^{151}$ and a fairly liquid capital market that quickly reflects the performance of a company. On the latter point, Professor Coffee predicts securities regulations and accounting systems will converge. ${ }^{152}$ Additionally, the establishment of property rights is indispensable for efficient corporate governance. ${ }^{153}$ Although this point would be considered as a matter of course among the developed countries, it is understandably important to observe the privatization struggle in the Eastern European countries and Russia. ${ }^{154}$

Most convergence debates also lack discussion of the relationship between corporate governance systems and their background economic markets. The optimal system for one particular economy may differ from another, depending on whether the economy is growing, matured, or declining. The convergence debates are useless unless these differences are taken into consideration. Japanese corporate governance is a fine example of an effective system for enlarging the economic pie but is not an effective system for sharing this pie.

If it is hypothesized that the United States and Japan share the same background economic market, would their corporate governance systems formally converge? This question leads to the debate on social norms versus economic institutions. One may argue that economic institutions will change social norms. ${ }^{155}$ Social norms going against economic institutions cannot survive in the competitive business system. ${ }^{156}$ There may be, however, many social norms which are not necessarily counter to economic institutions. Such a social norm could survive and play an important role in corporate governance. Good examples are the "Company Community" and

${ }^{149}$ See supra notes 93-103 and accompanying text (discussing how management can be stabilized by cross-shareholding).

${ }^{150}$ See Kaplan, supra note 80; Kaplan, supra note 90.

${ }^{15}$ See supra notes $115-19$ and accompanying text.

${ }^{152}$ See Coffee, supra note 4, at 699.

${ }^{153}$ See Harold Demsetz, Toward a Theory of Property Rights, 57 AM. Econ.REv. 347, 35459 (1967); Andrzej Rapaczynski, The Role of the State and the Market in Establishing Property Rights, 10 J. ECON. PERSP. 87, 88 (1996).

${ }^{14}$ See FrydMAN ET AL., supra note 119; Merritt Fox \& Michael A. Heller, Lessons from Fiascos in Russian Corporate Governance 33 (Working Paper, 1999).

${ }^{155}$ See Ramseyer, supra note 4, at 531.

${ }^{156}$ The business system which preserves economically unreasonable social norms cannot survive in the world competitive market. The Russian privatization process is an example. 
"Companyism" in Japanese corporate governance. These ideas contributed to the economic growth of Japan, but now during the recession, are losing their economic rationality and are subsequently struggling to survive.

\section{B. Destiny of the Company Community}

To predict the future of Japanese corporate governance is to predict the destiny of the Company Community. The Company Community has previously been an effective system to give the human capital providers the incentive to work hard. Today the inefficiencies of the Company Community have been revealed. Also, the premise behind the existence of the Company Community has lost credibility, such as to possibly lead to the disintegration of the lifetime employment system. The tough decision Japanese companies now must face is whether they should abandon the competitive advantage system of the Company Community and acquire a structure similar to the American system, or whether they should simply modify the competitive advantage system and keep the basics of the Company Community.

Whether the Company Community will survive or disappear may depend on the duration of the current recession. A longer recession will force shareholders and employees to share the decreasing pie. In such a situation, shareholders will use their control more often than usual and force management to layoff employees, thereby diminishing the idea of lifetime employment; the most important premise of the Company Community. This effect will be irreversible.

A statistical study comparing the worker turnover rate both in the United States and Japan throughout history displayed that during the 1920s and the 1930s, the turnover rate in both countries had remained almost equal. In the 1940s, however, the tumover rate in the United States jumped and has remained at a higher level than that of Japan. ${ }^{157}$ These statistics suggest that the Great Depression in the United States changed the labor management relationship in the United States.

Corporate governance systems exhibit points of strength and weakness. The Japanese system concentrates all human capital providers' incentives to the single interest of the company. ${ }^{153}$ There are three important problems in Japanese corporate governance that will force a change of the

${ }^{15}$ See Chiaki Moriguchi, The Evolution of Employment Systems in the U.S. and Japan, 1900-1960: A Comparative Historical and Institutional Analysis (Working Paper presented at the Changing Japanese Firm Conference at Columbia Business School, December 1998, at 33-38).

${ }^{153}$ See supra notes 107-14 and accompanying text (explaining how employees in Japanese corporations can have an interest comparable to an ownership interest without actually being shareholders). 
system. Two of these problems center on the monitoring of management. The third centers on inefficiencies arising from the equal treatment of employees in terms of wages and promotion, that are exaggerated significantly in conglomerate corporate structures.

First; there are few means available to fire ineffective management when they do not resign voluntarily. As mentioned previously, poor corporate performance necessitates management's self-resignation. The Company Community itself has few effective methods to force poor managers out. The second stage monitoring by the inside shareholders, while possibly more effective, takes too much time.

Second, there are few monitoring systems for shareholder interests through voice when their interests conflict with the interest of the Company Community. During the economic growth era, shareholders and employees shared almost the same interest, so shareholders were able to delegate monitoring to the Company Community. During this current recession the interests of shareholders and that of employees will conflict, particularly on the use of free cash flow. ${ }^{159}$

Solving these problems will require a monitoring unit independent of the Company Community. A possible way to create an independent monitoring unit by reforming the board of directors. The board of directors of Japanese companies has never played its monitoring role. Almost all members of the board other than the representative directors are junior management. The board of directors in Japan is not a part of the monitoring unit, but rather a part of the managing unit. In actuality, the board of directors does not monitor the CEO, rather the CEO monitors the board members. Having independent directors may contribute to make the board of directors play the role of monitor, particularly for representing shareholders' interests. ${ }^{160}$ Some Japanese companies have already introduced independent directors. ${ }^{161}$ Most Japanese companies, however, have difficulty with outsiders on their board for outside directors are foreign to the Company Community concept.

As noted above, the Company Community, when further combined with the standard problems of the conglomerate structure, develops two

${ }^{159}$ Observers of the Japanese economy suspect that many Japanese companies may have used free cash flow, which accued during the 1980s, not for increasing ROE, but for "empire building" i.e., overinvestment. For monitoring such a risk, the debate in the boardroom for the interest of shareholders is indispensable. See Watanabe \& Yamamoto, supra note 2, at 12.

${ }^{150}$ See, e.g., April Klein, Firm Performance and Board Committee Structure, 41 J. LAW \& ECON. 275, 280 (1998); Romano, supra note 148, at 297.

${ }^{16}$ Sony is the leader among Japanese firms in reforming the board system in Japan. Sony recently limited the number of board members to ten, with three outside directors and seven inside. Professor Nakatani of Hitotsubashi University was recently nominated to one of the outside director positions. NIKKEI, Mar. 30, 1999, at 15 (Japan). 
primary inefficiencies. First, the equal treatment required to maintain a Company Community leads to inefficiencies that are accentuated in the large conglomerate community structure. Second, the incentive benefits of the Company Community break down due to accountability problems in the conglomerate structure further leading to ambiguous performance of management units. These factors, combined with the lack of a monitoring unit independent of the managing unit, leads one to suggest that this structure tends to inefficiency.

The structure of holding companies may solve the difficult problem of introducing the independentmonitoring unit and decrease the inefficiency of conglomerates while maintaining the benefits of the Company Community. First, the Company Community should be conceptually defined at the same level as the management unit. A management unit is the smallest segment of a corporation maintaining individual, unit-specific, profit and balance sheet reporting structures. The social norm in Japan is to recognize each Company Community as a legal corporation. ${ }^{162}$ A holding company is a legal corporation consisting of several managing units, each having the status of a legal corporation. ${ }^{163}$ In terms of maximizing the beneficial aspects of the Company Community, the holding company should be preferred over the conglomerate.

At a fundamental level, the holding company structure respects the social norm that each legal corporation should maintain an individual Company Community. ${ }^{164}$ This structure also allows the holding company to escape the inefficiencies of the conglomerates. The holding company structure minimizes the inefficiencies of equal treatment within the corporation by allowing disparate treatment across company communities, while still maintaining the norm of equal treatment within. In a holding company, with the Company Community defined at the level of the management unit, the problem of ambiguous performance disappears because each unit or community reports on, and is accountable for, its own performance by definition. Finally, the holding company structure imposes the monitoring superstructure of its own management upon its subsidiary Company Communities. This solves the more general problem in Japanese governance of a lack of a monitoring unit independent of the managing unit.

Holding companies have only recently been recognized in Japan as a legitimate corporate structure. ${ }^{165}$ Notwithstanding, many companies have

\footnotetext{
${ }^{162}$ See Ito \& Shishido, supra note 77.

${ }^{163} \mathrm{~A}$ conglomerate corporation merges several management units into one.

${ }^{164}$ See supra notes 76-78 and accompanying text.

${ }^{165}$ Anti-Monopoly Law $\S 9$ (Reform of 1997).
} 
expressed an interest in pursuing this corporate form. ${ }^{166}$ The structure of holding companies suggests their relative success in Japan, for they solve, in part, the problems of conglomerates. Furthermore, holding companies tangibly represent the notion that while social norms fighting economic institutions will generally lose, economic institutions that change by utilizing non-conflicting social norms will improve upon any alternative.

\section{CONCLUSION}

In spite of its outside appearance, Japanese corporate governance has always kept the basics of the legal system of corporations, i.e., shareholder ownership as the end game norm. Otherwise, Japanese corporations would never have been so successful. The two distinct characteristics of Japanese corporate governance practice - cross-shareholding and "employee ownership" - are Japanese solutions to the hidden problems of corporate law: balancing between the monitoring and the autonomy of management; and balancing between human capital and money capital.

These characteristics are not solely Japanese phenomena. Every successful economy keeps the principle of shareholders' ownership and further develops its own methods to cope with these balancing issues. Background economic markets strongly influence those methods. Furthermore, the cultural and political influences are undeniable. In this sense, although details of corporate governance systems are path-dependent, the basics and the functions have already converged.

The change of the background economic market necessarily leads to changes in the Japanese corporate governance model. Once the growth of the Japanese economy has slowed or stopped, the Japanese stakeholder must share in a stable or decreasing pie, leading to further conflicts of interest. As a result, independent monitors for shareholders' interests become necessary. The decline in cross-shareholding is leading to the emergence of the corporate control market. Labor markets for employees are also emerging. In this new environment, the Company Community faces increased pressure to change.

No corporate governance system is perfect. There is always complementarity. The Japanese corporate governance system, which is based on the Company Community, has both the advantage of concentrating incentives of all human capital providers into the interest of the company, and the disadvantage of slow monitoring and waste from equal treatment.

${ }^{166}$ Mitsubishi Chemical has begun preparations for a change in their corporate structure to a holding company format. NiKKEI, Jan. 22, 1999, at 11 (Japan). Softbank has announced a similar strategy. NIKKEI, Feb. 11, 1999, at 11 (Japan). Industrial Bank of Japan is following suit as well. NIKKEI, Apr. 2, 1999, at 7 (Japan). 
The structure of a holding company, which has recently been deemed legitimate in Japan, is a commendable solution which may maintain the advantages of the Company Community while minimizing its relative disadvantages. 


\section{Figure 1}

The Ratio of Free Cash Flow to Plant and Equipment Investment

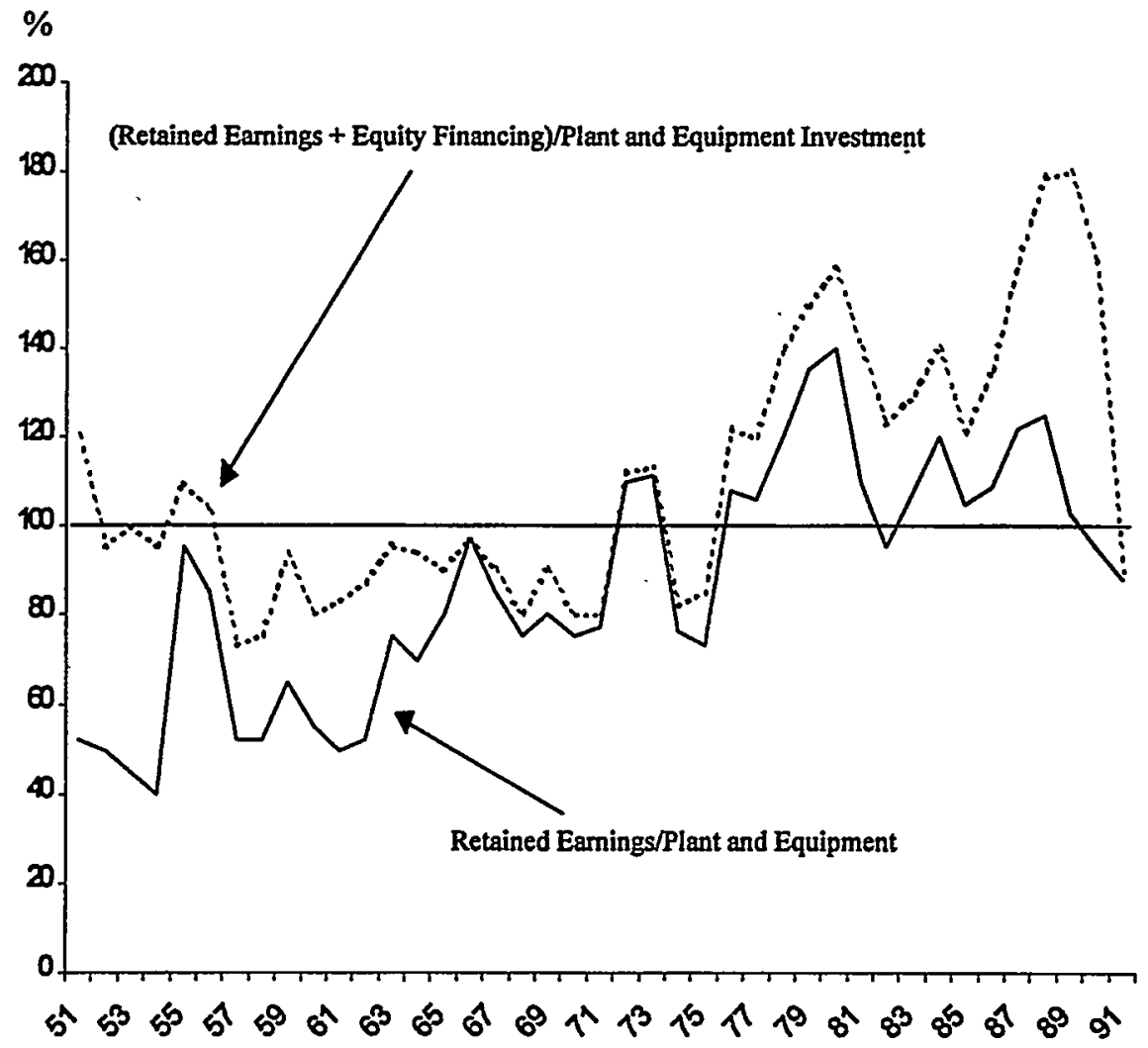

Shigeru Watanabe \& Isao Yamamoto, Nihon Kigyou no Kohporehto Gabanansu: Sengo Saitei no ROE kara [The Corporate Governance of Japanese Firms: The Lowest ROE after the War], 1992-9 Zaikai Kansoku (Business World Observer) 12.

Original data from Central Bank of Japan, The Management Analysis of Major Companies. 


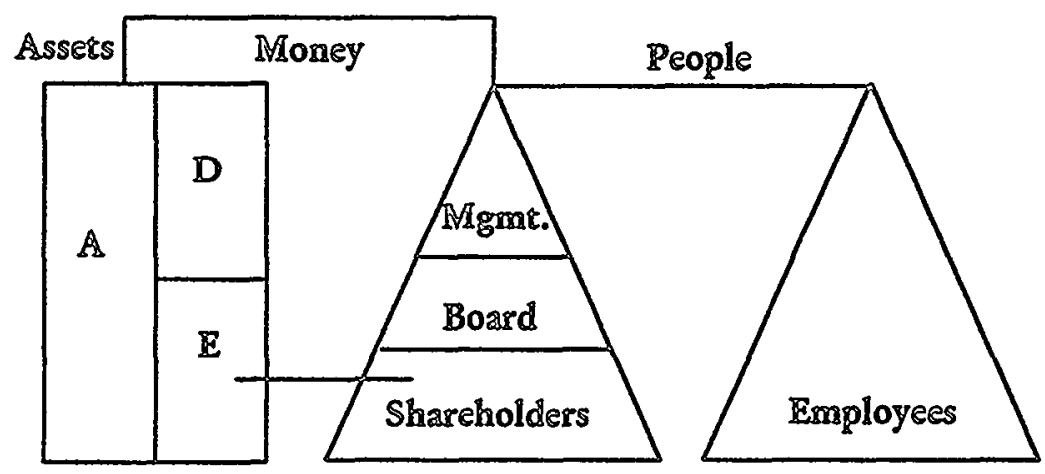

Figure 2 The Basic Legal Model of the Corporation 


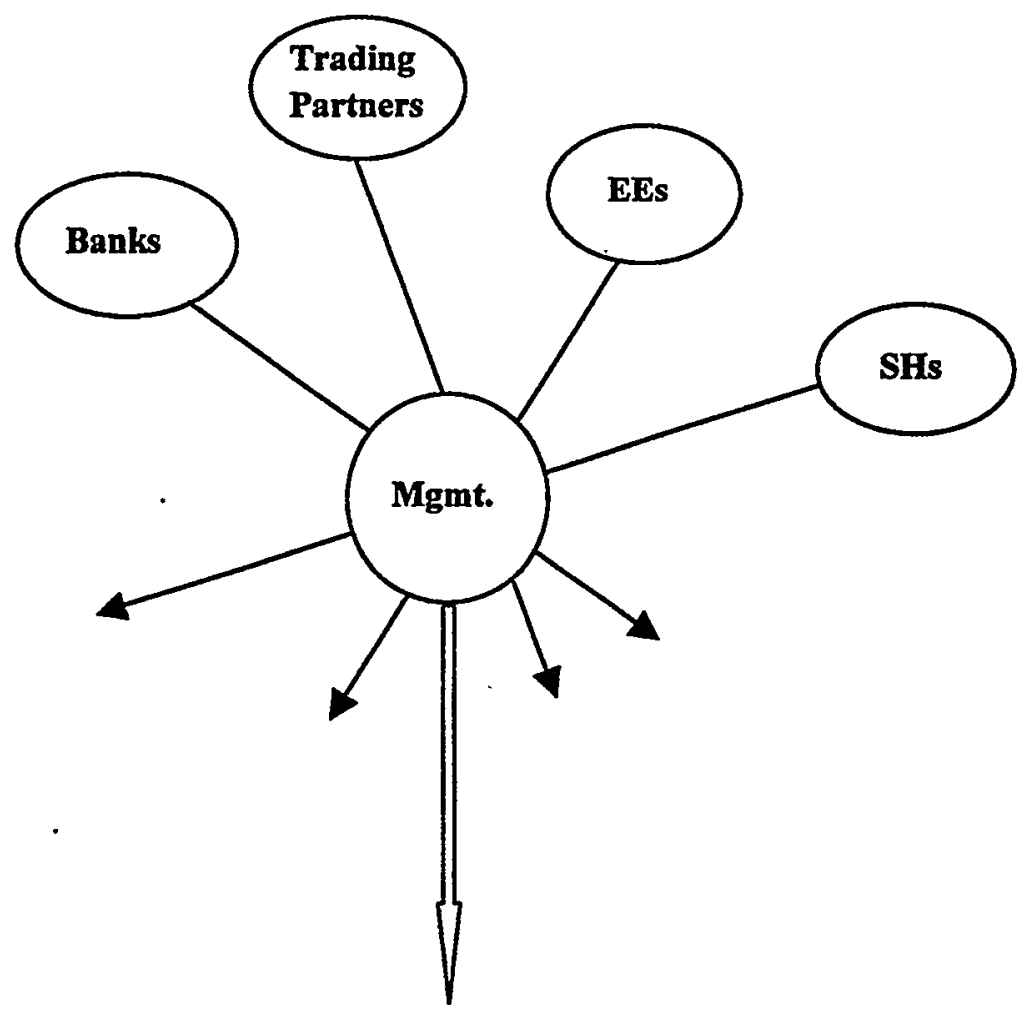

Figure 3 The Compound Vector of Monitoring 


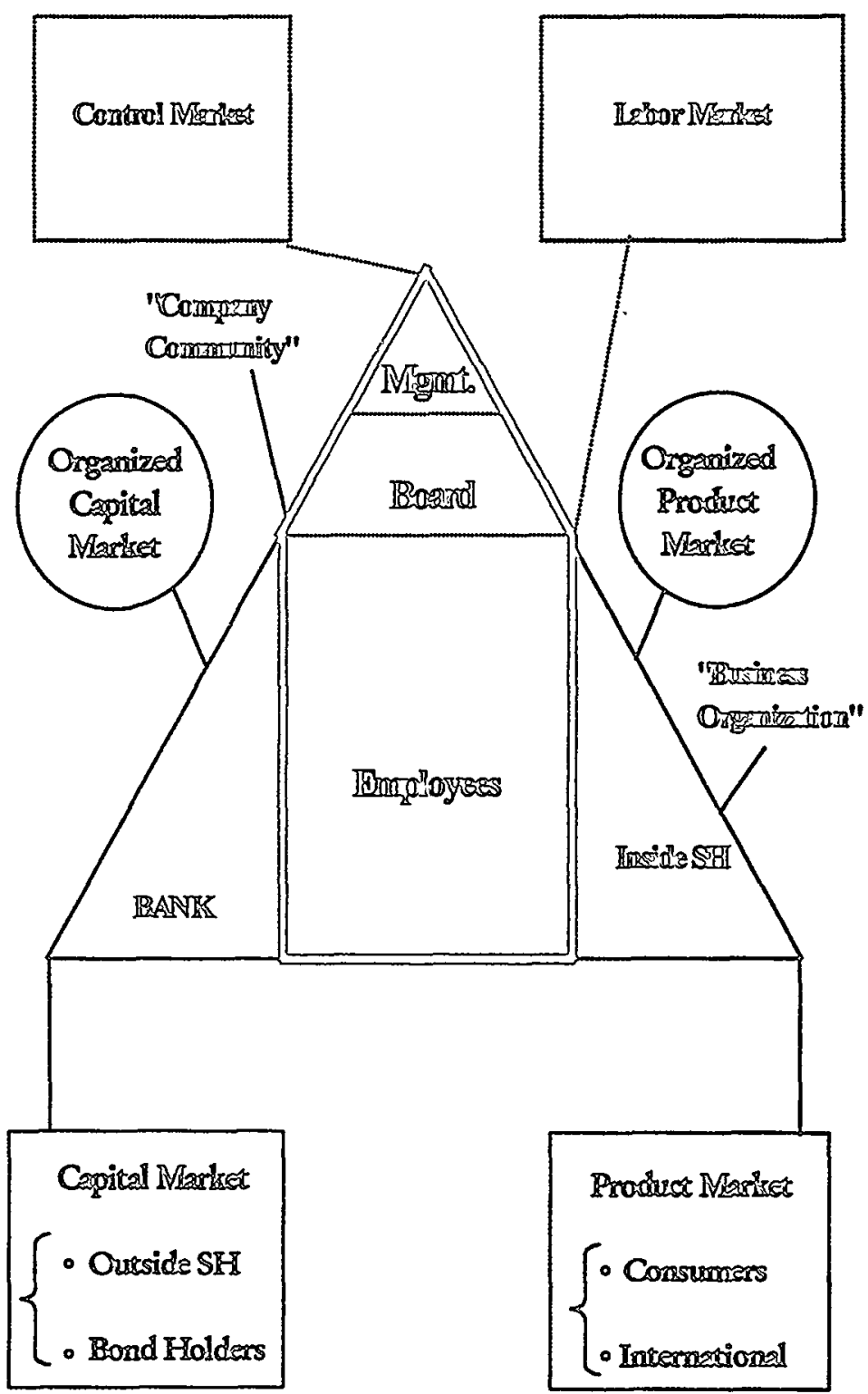

Ifigume 4

The Immze of the Ifprase Corpatete Gavemenge 
Figure 5 Share Turnover

Year Individuals Banks Insurance Co. Mutual Funds Other Corp. Foreigners

$\begin{array}{rrrrrrr}1975 & 74.6 & \cdot 3.2 & 3.4 & 96.4 & 16.5 & 48.8 \\ 1976 & 93.0 & 5.7 & 3.9 & 168.7 & 20.8 & \mathbf{7 2 . 8} \\ 1977 & 70.3 & 6.1 & 4.5 & 155.1 & 18.3 & \mathbf{7 0 . 3} \\ 1978 & 98.3 & 9.7 & 4.8 & 203.8 & 25.5 & 97.0 \\ 1979 & 89.4 & 12.7 & 3.8 & 136.5 & 26.1 & 78.3 \\ 1980 & 82.1 & 12.1 & 3.8 & 122.7 & 25.8 & 92.0 \\ 1981 & 93.6 & 11.8 & 3.1 & 148.1 & 26.6 & 125.3 \\ 1982 & 66.8 & 7.6 & 2.9 & 115.5 & 17.9 & 91.9 \\ 1983 & 84.5 & 9.3 & 2.9 & 163.4 & 22.4 & 113.8 \\ 1984 & 88.6 & 13.6 & 2.6 & 190.7 & 24.0 & 115.1 \\ 1985 & 74.6 & 20.8 & 2.3 & 147.5 & 21.9 & 91.7 \\ 1986 & 93.2 & 45.6 & 3.2 & 210.5 & 38.5 & 144.9 \\ 1987 & 89.0 & 54.5 & 2.9 & 185.5 & 42.4 & 205.8\end{array}$

Nissei Tohshi Kenkyuhkai (Japan Life Insurance Workshop on Investment), Senryakuteki Shohken Tohshi (Tactical Stock Investment) 85 (1989). 


\begin{tabular}{|c|c|c|c|c|c|c|c|c|c|c|c|c|c|c|c|c|c|}
\hline \multirow{5}{*}{ 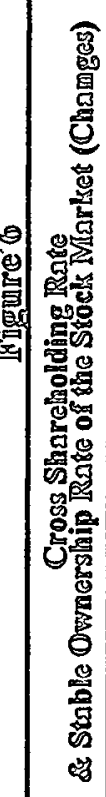 } & & \multirow{2}{*}{ 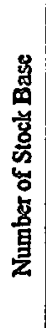 } & 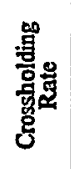 & & $\mid \begin{array}{l}n \\
0 \\
\\
4\end{array}$ & $\begin{array}{l}\square \\
\\
\end{array}$ & $\frac{\infty}{0}$ & 車 & 今 & \begin{tabular}{|c|}
$\overrightarrow{0}$ \\
$\dot{4}$
\end{tabular} & 悉 & స్తి & $\begin{array}{l}\overline{0} \\
8\end{array}$ & $\stackrel{8}{\circ}$ & $\begin{array}{l}\text { : } \\
\text { ¿े }\end{array}$ & $\stackrel{\widetilde{\sigma}}{4}$ & \\
\hline & & & 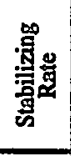 & & $\begin{array}{l}\overrightarrow{\mathbf{s}} \\
0 \\
\Delta\end{array}$ & 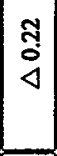 & 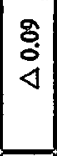 & ‡: & $\begin{array}{l}\text { गे } \\
\text { Oे } \\
4\end{array}$ & 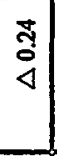 & $\stackrel{\widetilde{\Xi}}{4}$ & $\begin{array}{l}m \\
0 \\
\dot{0}\end{array}$ & 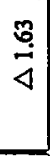 & 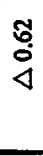 & $\frac{h_{2}^{\infty}}{4}$ & $\frac{5}{3}$ & \\
\hline & & \multirow{3}{*}{ 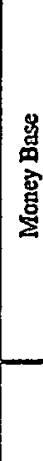 } & 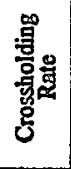 & & $\begin{array}{l}0 \\
0 \\
0 \\
4\end{array}$ & $\mid \begin{array}{l}0 \\
0 \\
0 \\
4\end{array}$ & $\begin{array}{l}8 \\
0 \\
4 \\
4\end{array}$ & $\cong$ & $\begin{array}{l}0 \\
0 \\
\end{array}$ & $\bar{z}$ & \begin{tabular}{l}
7 \\
\multirow{0}{0}{} \\
$\triangleleft$
\end{tabular} & $\begin{array}{l}5 \\
0 \\
0 \\
4\end{array}$ & $\begin{array}{l}\text { iें } \\
\dot{0} \\
\dot{q}\end{array}$ & $\begin{array}{l}\text { sి } \\
\text { d }\end{array}$ & $\frac{\sqrt[m]{2}}{\triangleleft}$ & $\stackrel{5}{i}$ & 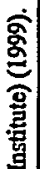 \\
\hline & & & 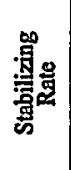 & & 包 & $\frac{n}{0}$ & $\begin{array}{l}\alpha \\
\partial \\
\dot{\jmath}\end{array}$ & $\stackrel{n}{6}$ & : & $\dddot{7}$ & $\begin{array}{l}\text { के } \\
\text { ठे }\end{array}$ & 웅 & $\frac{\pi}{4}$ & $\underset{\square}{\exists}$ & $\stackrel{\text { ô }}{4}$ & 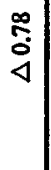 & \\
\hline & & & $\underbrace{3}_{>}$ & $\begin{array}{l}\stackrel{\Xi}{\Xi} \\
\stackrel{2}{\circ}\end{array}$ & ळ & 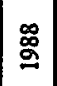 & 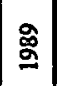 & \% & $\overline{\mathrm{g}}$ & $\underline{\tilde{\delta}}$ & $\stackrel{\varrho}{\sigma}$ & 盇 & ڤ్ & ఓ & ఏ్ & $\stackrel{\infty}{\varrho}$ & \\
\hline \multirow{5}{*}{ 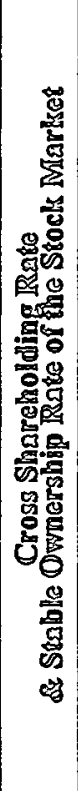 } & 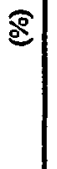 & \multirow{2}{*}{ 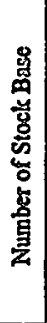 } & 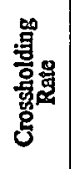 & 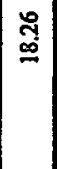 & $\overline{=}$ & $\stackrel{5}{=}$ & 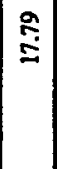 & \begin{tabular}{|l}
$\tilde{\sigma}$ \\
$\stackrel{\Phi}{0}$
\end{tabular} & 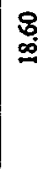 & 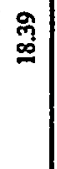 & $\stackrel{\circ}{\Xi}$ & 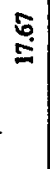 & $\stackrel{0}{\Xi}$ & 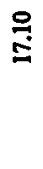 & 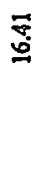 & शे & \\
\hline & & & 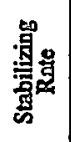 & 总 & $\frac{0}{8}$ & $\begin{array}{c}\infty \\
0 \\
8 \\
8\end{array}$ & 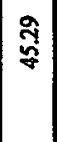 & $\frac{n}{8}$ & $\bar{\sigma}$ & $\bar{\phi}$ & $\frac{7}{5}$ & 帝 & $\stackrel{9}{\forall}$ & 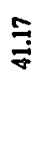 & ڤ్ & శ్ర్ల & $\begin{array}{l}\text { 离 } \\
\text { 㺃 }\end{array}$ \\
\hline & \multirow{2}{*}{\multicolumn{2}{|c|}{ 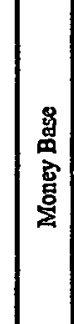 }} & 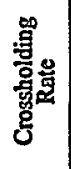 & $\stackrel{\leftrightarrow}{\stackrel{s}{*}}$ & $\underset{\dot{i}}{\mathrm{i}}$ & $\stackrel{8}{\mathrm{i}}$ & 号 & 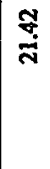 & $\frac{\pi}{\tilde{N}}$ & $\overline{\bar{y}}$ & ثิ & 尽 & के & ฟึ้ & $\stackrel{9}{\Phi}$ & $\begin{array}{l}\text { : } \\
0 \\
0\end{array}$ & 費 \\
\hline & & & 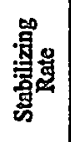 & \begin{tabular}{|}
$\bar{a}$ \\
$\dot{\alpha}$ \\
$\sigma$
\end{tabular} & $\underset{⿱ 亠 乂}{\sigma}$ & : & 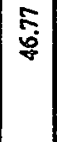 & $\frac{\tilde{2}}{5}$ & 栾 & 5 & $\begin{array}{l}\text { \%̊ } \\
\text { హे }\end{array}$ & 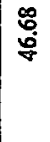 & $\frac{\pi}{8}$ & శ్ & 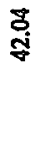 & ఫ্] & \\
\hline & & & 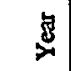 & ळ & $\stackrel{心}{\cong}$ & $\begin{array}{l}\text { \% } \\
\stackrel{2}{\circ}\end{array}$ & 骨 & హ్ & $\vec{\alpha}$ & $\Phi$ & 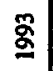 & 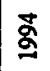 & 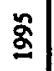 & ঞ & s & \% & \\
\hline
\end{tabular}


Table 7

Sources of Corporate Financing (manufacturing)

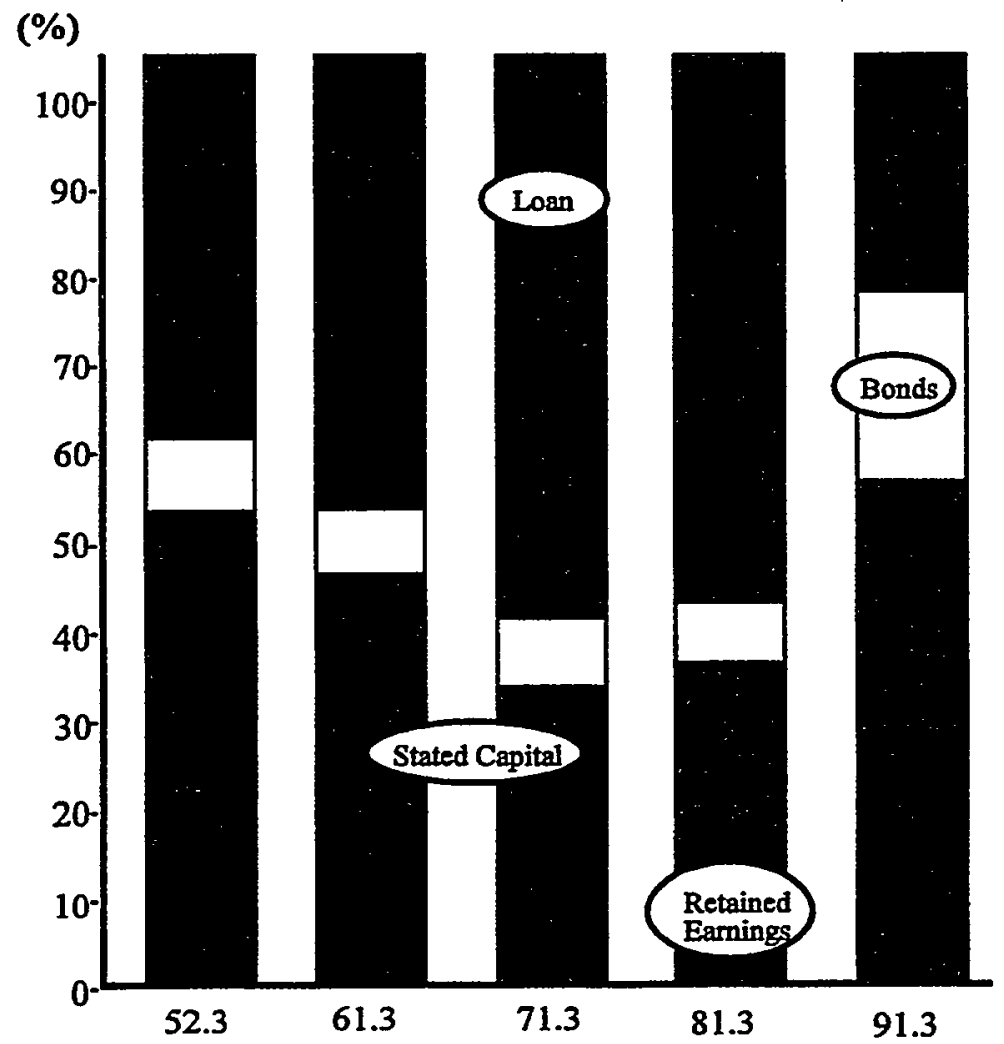

Shigeru Watanabe \& Isao Yamamoto, Nihon Kigyou no Kohporehto Gabanansu: Sengo Saitei no ROE kara [The Corporate Governance of Japanese Firms: The Lowest ROE after the War], 1992-9 Zaikai Kansoku (Business World Observer) 12. 
HeinOnline -- 25 Del. J. Corp. L. 2342000 